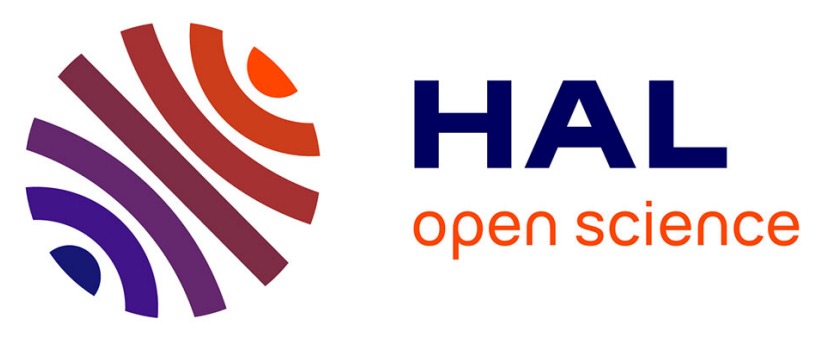

\title{
The Utility of Optical Satellite Winter Snow Depths for Initializing a Glacio-Hydrological Model of a High-Elevation, Andean Catchment
}

Thomas E Shaw, Alexis Caro, Pablo Mendoza, Álvaro Ayala, Francesca Pellicciotti, Simon Gascoin, James Mcphee

\section{To cite this version:}

Thomas E Shaw, Alexis Caro, Pablo Mendoza, Álvaro Ayala, Francesca Pellicciotti, et al.. The Utility of Optical Satellite Winter Snow Depths for Initializing a Glacio-Hydrological Model of a High-Elevation, Andean Catchment. Water Resources Research, 2020, 56 (8), pp.1-19. 10.1029/2020wr027188 . hal-02997105

\section{HAL Id: hal-02997105 https://hal.science/hal-02997105}

Submitted on 18 Nov 2020

HAL is a multi-disciplinary open access archive for the deposit and dissemination of scientific research documents, whether they are published or not. The documents may come from teaching and research institutions in France or abroad, or from public or private research centers.
L'archive ouverte pluridisciplinaire HAL, est destinée au dépôt et à la diffusion de documents scientifiques de niveau recherche, publiés ou non, émanant des établissements d'enseignement et de recherche français ou étrangers, des laboratoires publics ou privés. 


\section{Water Resources Research}

\section{RESEARCH ARTICLE 10.1029/2020WR027188 \\ Key Points: \\ - Pléiades snow depths aid simulation \\ The Utility of Optical Satellite Winter Snow Depths for Initializing a Glacio-Hydrological Model of a High-Elevation, Andean Catchment} of snow cover extent, glacier mass balance, and monthly streamflow

- Alternative snow depth initial conditions underestimate early spring streamflow by up to $48 \%$

- Sensitivity to temperature means estimating total snow volume with elevation is most important to model snowmelt and streamflow

Supporting Information:

- Supporting Information S1

Correspondence to:

T. E. Shaw,

thomas.shaw@amtc.uchile.cl

Citation:

Shaw, T. E., Caro, A., Mendoza, P. Ayala, Á., Pellicciotti, F., \& Gascoin, S., et al. (2020). The utility of optical satellite winter snow depths for initializing a glacio-hydrological model of a high-elevation, Andean catchment. Water Resources Research, 56, e2020WR027188. https://doi.org/ 10.1029/2020WR027188

Received 21 JAN 2020

Accepted 16 JUN 2020

Accepted article online 20 JUN 20

Author Contributions:

Conceptualization: Thomas E. Shaw,

Francesca Pellicciotti, Simon Gascoin,

James McPhee

Investigation: Thomas E. Shaw, Alexi Caro

Methodology: Thomas E. Shaw, Pablo Mendoza, Álvaro Ayala, Simon Gascoin Resources: Simon Gascoin, James McPhee

Writing - original draft: Thomas E. Shaw

\author{
Thomas E. Shaw ${ }^{1}$ (D), Alexis Caro ${ }^{1,2}$, Pablo Mendoza ${ }^{3}$ (D), Álvaro Ayala ${ }^{4}$ (D), \\ Francesca Pellicciotti ${ }^{5,6}$ (D), Simon Gascoin ${ }^{7}$ (D), and James McPhee ${ }^{1,3}$ iD \\ ${ }^{1}$ Advanced Mining Technology Center, Universidad de Chile, Santiago, Chile, ${ }^{2}$ University Grenoble Alpes, CNRS, IRD, \\ Grenoble-INP, Institut des Géosciences de l'Environnement (IGE, UMR 5001), Grenoble, France, ${ }^{3}$ Department of Civil \\ Engineering, Universidad de Chile, Santiago, Chile, ${ }^{4}$ Centro de Estudios Avanzados en Zonas Áridas (CEAZA), La Serena, \\ Chile, ${ }^{5}$ Federal Institute for Forest, Snow and Landscape Research (WSL), Birmensdorf, Switzerland, ${ }^{6}$ Department of \\ Geography, Northumbria University, Newcastle, UK, ${ }^{7} \mathrm{CESBIO}$, Université de Toulouse, CNES/CNRS/INRA/IRD/UPS, \\ Toulouse, France
}

Abstract Information about end-of-winter spatial distribution of snow depth is important for seasonal forecasts of spring/summer streamflow in high-mountain regions. Nevertheless, such information typically relies upon extrapolation from a sparse network of observations at low elevations. Here, we test the potential of high-resolution snow depth data derived from optical stereophotogrammetry of Pléiades satellites for improving the representation of snow depth initial conditions (SDICs) in a glacio-hydrological model and assess potential improvements in the skill of snowmelt and streamflow simulations in a high-elevation Andean catchment. We calibrate model parameters controlling glacier mass balance and snow cover evolution using ground-based and satellite observations, and consider the relative importance of accurate estimates of SDICs compared to model parameters and forcings. We find that Pléiades SDICs improve the simulation of snow-covered area, glacier mass balance, and monthly streamflow compared to alternative SDICs based upon extrapolation of meteorological variables or statistical methods to estimate SDICs based upon topography. Model simulations are found to be sensitive to SDICs in the early spring (up to $48 \%$ variability in modeled streamflow compared to the best estimate model), and to temperature gradients in all months that control albedo and melt rates over a large elevation range $(>2,400 \mathrm{~m})$. As such, appropriately characterizing the distribution of total snow volume with elevation is important for reproducing total streamflow and the proportions of snowmelt. Therefore, optical stereo-photogrammetry offers an advantage for obtaining SDICs that aid both the timing and magnitude of streamflow simulations, process representation (e.g., snow cover evolution) and has the potential for large spatial domains.

\section{Introduction}

Seasonal snow cover is a dominant source of fresh water for many of the world's mountainous regions and of crucial importance to the rivers for adjacent lowland areas (Barnett et al., 2005; Mankin et al., 2015; Meza et al., 2012; Viviroli et al., 2007). For example, snowmelt provides more than $75 \%$ of the total freshwater in the western United States (Bales et al., 2006). This contribution can be 30-65\% in large catchments of the Himalayas (Armstrong et al., 2019; Brown et al., 2014; Ragettli et al., 2016; Shrestha et al., 2015) and between 50\% and 93\% in glacierized catchments of the central Andes (Ayala et al., 2016, 2019; Burger et al., 2018), depending on the outlet elevation and degree of glacierization. Because of rising global average temperatures and reduction in snowpack extents (Mernild et al., 2016), some streamflow properties at these lowland areas are changing, such as seasonality, diminishing annual volumes (Garreaud et al., 2017, 2019; Kormos et al., 2016) or a stronger reliance on contributions from shrinking mountain glaciers (Burger, Brock, \& Montecinos, 2018; Lane \& Nienow, 2019; Nolin et al., 2010; Ohlanders \& Mcphee, 2013; Ragettli et al., 2016; Riedel et al., 2015).

In central Chile $\left(30-38^{\circ} \mathrm{S}\right)$, a decreasing trend in seasonal snow cover (Mernild et al., 2016) has resulted from a long-term (decadal) downward trend in annual precipitation (Boisier et al., 2016; Burger et al., 2018), increasing mean annual air temperatures (Burger, Ayala, et al., 2018) and recent prolonged periods of 
drought (Boisier et al., 2016; Garreaud et al., 2017, 2019). The result is an increasing contribution of ice melt to annual streamflow (Ayala et al., 2020; Burger, Brock, \& Montecinos, 2018) and a vulnerable future situation for water rights and demands for irrigation and the mining industry (Meza et al., 2012, 2015). However, the large-elevation gradient and the lack of in situ observations for meteorology and snow hydrology in the Andes range hinders our understanding and capability to quantify snow water equivalent in high mountain domains (Alvarez-Garreton et al., 2018; Cornwell et al., 2016; Cortés et al., 2016; Favier et al., 2009; Shaw, Gascoin, et al., 2020). Complex interactions of mountainous topography and meteorological processes determine the spatial distribution of snow water equivalent at high elevations (Freudiger et al., 2017; Gascoin et al., 2013), though detailed understanding of these processes are limited by the availability and distribution of observations (Stehr \& Aguayo, 2017) and/or the high computational demands of complex physically based models (Musselman et al., 2015; Vionnet et al., 2017).

As a result, there are large uncertainties in the initial conditions of snow water equivalent (SWE) required to simulate spring-summer streamflow from physically based or statistical glacio-hydrological models (e.g., Mendoza et al., 2014; Stigter et al., 2017). Such initial conditions are often derived by calibrating precipitation gradients against point-based observations (e.g., Ayala et al., 2016; Ragettli \& Pellicciotti, 2012). Precipitation gradients are extremely difficult to characterize in mountain regions because of the lack of rainfall gauges and the fact that many other processes, together with precipitation, determine snow accumulation on the ground (Houze, 2012; Scaff et al., 2017). In addition to large uncertainties associated with wind-induced undercatch errors (Sevruk et al., 2009), the selection of appropriate forcing stations may not always be clear. This is because the spatiotemporal evolution of mountain storm events may not be uniformly detected by all stations under analysis (Ragettli et al., 2014). At these local scales, orographic precipitation combines with other topographic and microphysical processes to shape complex precipitation and snow accumulation patterns in mountainous terrain (Roth et al., 2018; Vionnet et al., 2017). Although gridded or dynamically downscaled products (e.g., WRF-"Weather Research and Forecasting Model") have shown promise in improving representation of precipitation for glacier mass balance modeling (e.g., Jarosch et al., 2012) or SWE (e.g., Baba et al., 2018), such regional climate model scenarios are still too computationally expensive to derive information at resolutions necessary to resolve orographic precipitation effects (Gutmann et al., 2016) and remain prone to large uncertainties (Réveillet et al., 2020).

Accordingly, quantifying SWE at the watershed scale for a single winter season can be inherently challenging and is often hindered by site accessibility (López-Moreno \& Nogués-Bravo, 2006), the limited spatial extent of terrestrial survey techniques (Revuelto et al., 2014) or cost of airborne surveys (Painter et al., 2016). The development of low-cost drone-based stereo imaging has gained much popularity in monitoring snow depths recently (e.g., Avanzi et al., 2018; Bühler et al., 2016; Goetz \& Brenning, 2019; Redpath et al., 2018), though it is still limited in terms of the spatial coverage it can provide. The recent development of low-cost, high-resolution techniques for deriving spatial snow depths from optical satellite imagery provides new opportunities to understand snow patterns at high elevations and produce snow initial conditions for seasonal hydrological simulations. Marti et al. (2016) derived 1-4 m resolution snow depth maps by differencing digital elevation models (DEMs) derived from tristereo pairs of Pléiades optical satellite images. The methodology produced decimetric accuracy of snow depths for a Pyrenean study basin and was recently tested for a high-mountain site in the central Chilean Andes by Shaw, Gascoin, et al. (2020). Similar efforts using World-View 3 imagery have been recently made to observe snow depths in the western United States (McGrath et al., 2019).

In this study, we utilize the spatial snow depth information provided by Pléiades satellites in Shaw, Gascoin, et al. (2020) to force the physically oriented glacio-hydrological model TOPKAPI-ETH for a snow-dominated, glacierized catchment of central Chile. The aims are to (i) evaluate the utility of an end-of-winter satellite snow depth map for simulating seasonal snowmelt and streamflow, (ii) compare model simulations produced with a control approach of not updating snow conditions and alternative snow depth initial conditions based upon existing methodologies, and (iii) test the sensitivity of modeled streamflow to snow depth initial conditions in the context of other parameter and forcing uncertainties. We first present the study site and main data sets in sections 2 and 3. Section 4 focuses upon the methodological approach to evaluate the utility of Pléiades for glacio-hydrological modeling, and section 5 presents the results. 


\section{Study Site}

The Río Yeso catchment ( $12 \%$ glacierized) is located in the Andes of central Chile $\left(33.44^{\circ} \mathrm{S}, 69.93^{\circ} \mathrm{W}\right)$ and is one of the tributaries to the Yeso Reservoir and the Maipo River, which are key drinking provisions for the country's capital, Santiago (Figure 1). The snow-dominated catchment has an area of $102 \mathrm{~km}^{2}$ with an elevation range of $\sim 2,900-5,400 \mathrm{~m}$ above sea level (a.s.l.). There are three main glaciers in the basin-Bello $\left(4.6 \mathrm{~km}^{2}\right)$, Yeso $\left(2.9 \mathrm{~km}^{2}\right)$, and Pirámide $\left(4.7 \mathrm{~km}^{2}\right.$, debris-covered) which have been shown to contribute between $3 \%$ and $32 \%$ of the basin's spring-summer streamflow through ice melt (Burger, Brock, \& Montecinos, 2018). Piramide Glacier has an estimated debris thickness ranging from 0.01 to $>0.6 \mathrm{~m}$, which controls ice melt spatial distribution, and has an accumulation area largely influenced by mixed avalanches within its steep-sided valley basin (Ayala et al., 2016; Burger, Brock, \& Montecinos, 2018). The mass balance of glaciers Bello and Yeso are governed more strongly by temperature lapse rates associated with elevation differences (Ayala et al., 2016), though the mass balance of the former is strongly influenced by wind remobilization of snow along its flowline (Shaw, Gascoin, et al., 2020). The catchment is dominated by shallow entisol soils and steep terrain (average slope of $27^{\circ}$ ) that supports typically small sclerophyllous vegetation.

\section{Data}

\subsection{Remotely Sensed Data}

The main initial snow depth was provided by vertical differencing of DEMs constructed by tristereo registration of optical Pléiades images at a raw output resolution of $0.7 \mathrm{~m}$ (Marti et al., 2016). The images were aligned and processed in the NASA Ames Stereo Pipeline (Shean et al., 2016) using multiview stereo and without ground control points. The resultant DEMs were aligned to each other by relative coregistration of snow-free surfaces with a slope of $<40^{\circ}$ (Berthier et al., 2007) and tied to an absolute spatial reference against a terrestrial LiDAR (Light Ranging and Detection) scan with differential GPS geolocation. An uncertainty estimate of $0.36 \mathrm{~m}$ was derived from evaluation of the Pléiades snow depth product against the LiDAR reference data set. For details, we refer the reader to Shaw, Gascoin, et al. (2020). The processed Pléiades map is presented at a common spatial resolution of $30 \mathrm{~m}$ for modeling purposes (resampled by bilinear interpolation), and displays a nonlinear relationship of snow depth with elevation (Shaw, Gascoin, et al., 2020). Variogram analysis have demonstrated that the correlation length of the error field in Pléiades snow depth maps at other sites is about $25 \mathrm{~m}$ (Deschamps-Berger et al., 2020). Hence, the random error should be minimized by spatial averaging at a common $30 \mathrm{~m}$ resolution. We utilized the snow-free DEM of Pleiades (acquired January, 2018), resampled to a $30 \mathrm{~m}$ horizontal resolution through bilinear interpolation, to run the TOPKAPI-ETH model (see section 4).

We calculated catchment-wide fractional snow cover area (fSCA) from daily MODIS MOD10A1 V6. "NDSI_Snow_Cover" tiles that use a normalized differential snow index (NDSI) at a horizontal resolution of $500 \mathrm{~m}$ (Hall et al., 2010). For each day, we consider a NDSI threshold of 0.2 for snow cover presence and calculate the total fraction of the catchment that is covered by snow. We additionally obtained cloud-free optical images of PlanetScope satellites (PlanetTeam, 2018) at a $3 \mathrm{~m}$ resolution for (i) calibrating solid precipitation thresholds, and (ii) model evaluation (section 4.5). PlanetScope images were obtained typically for dates following snow storm events and were georeferenced to the Pléiades snow-free orthoimage using manually identified bedrock features.

\subsection{Meteorological Data}

Meteorological information was provided by automatic weather stations (AWS) of (i) the Chilean water directorate (Dirección General de Aguas or "DGA"), and (ii) stations specifically installed by our group for the project "Estudio del aporte glaciar en la cuenca del río Maipo", developed by Cetaqua/Untec for Aguas Andinas, Sociedad del Canal de Maipo y Junta de Vigilancia del río Maipo (hereafter "Aguas Andinas"Figure 1). For the period of interest (4 September 2017 to 31 March 2018), hourly data were available off-glacier from online archives of DGA and on-glacier for a shorter period of observation (see Table 1). DGA stations Yeso Embalse, San Francisco, Laguna Negra, and Termas del Plomo were utilized to extract near-surface air temperature. Precipitation data were obtained from Yeso Embalse, Termas del Plomo, and additional DGA stations (not shown) in a longitudinal corridor from the Chilean coast (elevation range of 2,995 m) to compute precipitation gradients (section 4.2). 

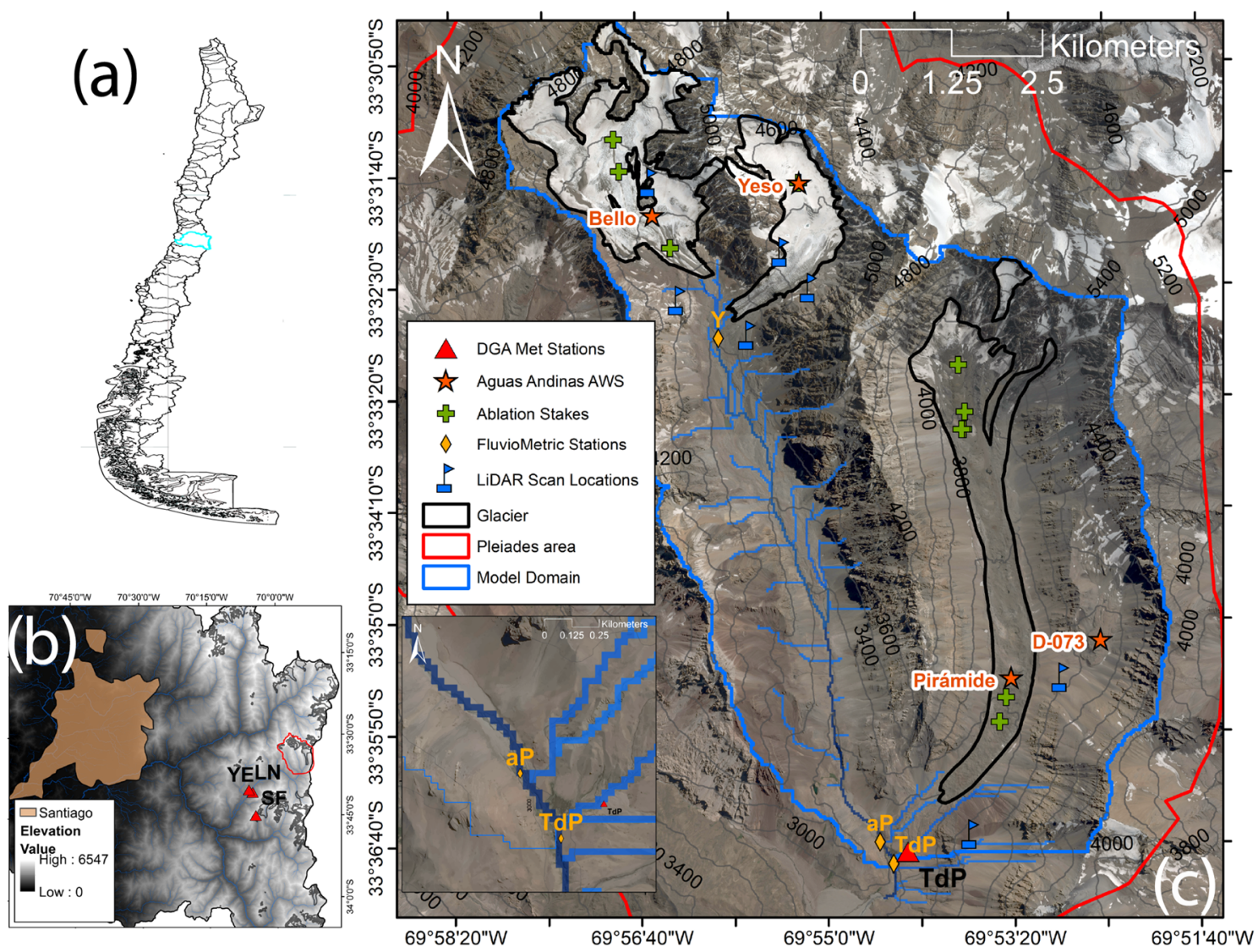

Figure 1. Map of the study basin, Río Yeso, with location of site within Chile (a) and the metropolitan region (b). The original Pléiades acquisition area and model domain are shown by the red and blue lines, respectively, in (c). Individual LiDAR locations (blue flags) were used to construct DEMs from multiple angles. Background satellite image source: PlanetScope, March 2017. Stream order (Strahler) is shown based upon the Pléiades snow-free DEM. The inset of (c) is plotted to show the locations of streamflow stations "aP" and "TdP" relative to the stream origins.

Each on-glacier AWS measured air temperature $\left({ }^{\circ} \mathrm{C}\right)$, relative humidity $(\%)$, four-component radiation $\left(\mathrm{W} \mathrm{m}^{-2}\right)$, wind speed $\left(\mathrm{m} \mathrm{s}^{-1}\right)$, and direction $\left(^{\circ}\right)$, which were stored as instantaneous 10 min values. Values were averaged to an hourly time step consistent with DGA measurements and the model configuration.

Table 1

Hydrometeorological Stations of This Study, Including Available Date Ranges and Data Gaps

\begin{tabular}{|c|c|c|c|c|c|}
\hline Station & Source & Elevation (m a.s.l.) & Variables + & Date range & $\%$ data gaps $^{\mathrm{a}}$ \\
\hline Termas del Plomo (TdP) & DGA & 2,995 & Ta, RH, RadNET, WS, WD, P & $4 / 9 / 2017$ to $31 / 3 / 2018$ & 0.7 \\
\hline Yeso Embalse (YE) & DGA & 2,475 & $\mathrm{Ta}, \mathrm{P}$ & $4 / 9 / 2017$ to $31 / 3 / 2018$ & 0 \\
\hline San Francisco (SF) & DGA & 2,220 & Ta, $\mathrm{P}$ & $4 / 9 / 2017$ to $31 / 3 / 2018$ & 0 \\
\hline Laguna Negra (LN) & DGA & 2,770 & $\mathrm{Ta}$ & $4 / 9 / 2017$ to $31 / 3 / 2018$ & 0 \\
\hline AWS Bello & Aguas Andinas & 4,214 & Ta, RH, RadNET, WS, WD, SDG & $25 / 10 / 2017$ to $31 / 3 / 2018$ & 12.3 \\
\hline AWS Yeso & Aguas Andinas & 4,470 & Ta, RH, RadNET, WS, WD, SDG & $22 / 11 / 2017$ to $31 / 3 / 2018$ & 3.9 \\
\hline AWS Piramide & Aguas Andinas & 3,437 & Ta, RH, RadNET, WS, WD & $22 / 11 / 2017$ to $31 / 3 / 2018$ & 6.4 \\
\hline AWS D-073 & Aguas Andinas & 3,744 & Ta, RH, RadNET, WS, WD & $22 / 11 / 2017$ to $31 / 3 / 2018$ & 17 \\
\hline F_TdP & Aguas Andinas & 3,015 & wPa & $15 / 9 / 2017$ to $31 / 3 / 2018$ & 30 \\
\hline F_aP & Aguas Andinas & 3,020 & wPa & $22 / 11 / 2017$ to $31 / 3 / 2018$ & 0 \\
\hline F_Y & Aguas Andinas & 3,820 & wPa & $22 / 11 / 2017$ to $31 / 3 / 2018$ & 56.7 \\
\hline
\end{tabular}

Note 十 $\mathrm{Ta}=$ Air temperature, $\mathrm{P}=$ precipitation, $\mathrm{RH}=$ relative humidity, RadNET $=$ net radiation, $\mathrm{WS}=$ wind speed, $\mathrm{WD}=$ wind direction, $\mathrm{SDG}=\mathrm{ultrasonic}$ depth gauge, $\mathrm{wPa}=$ water pressure. Dates are formatted as day/month/year.

${ }^{a}$ Data gaps are percentages of the total available within the specified date ranges. 


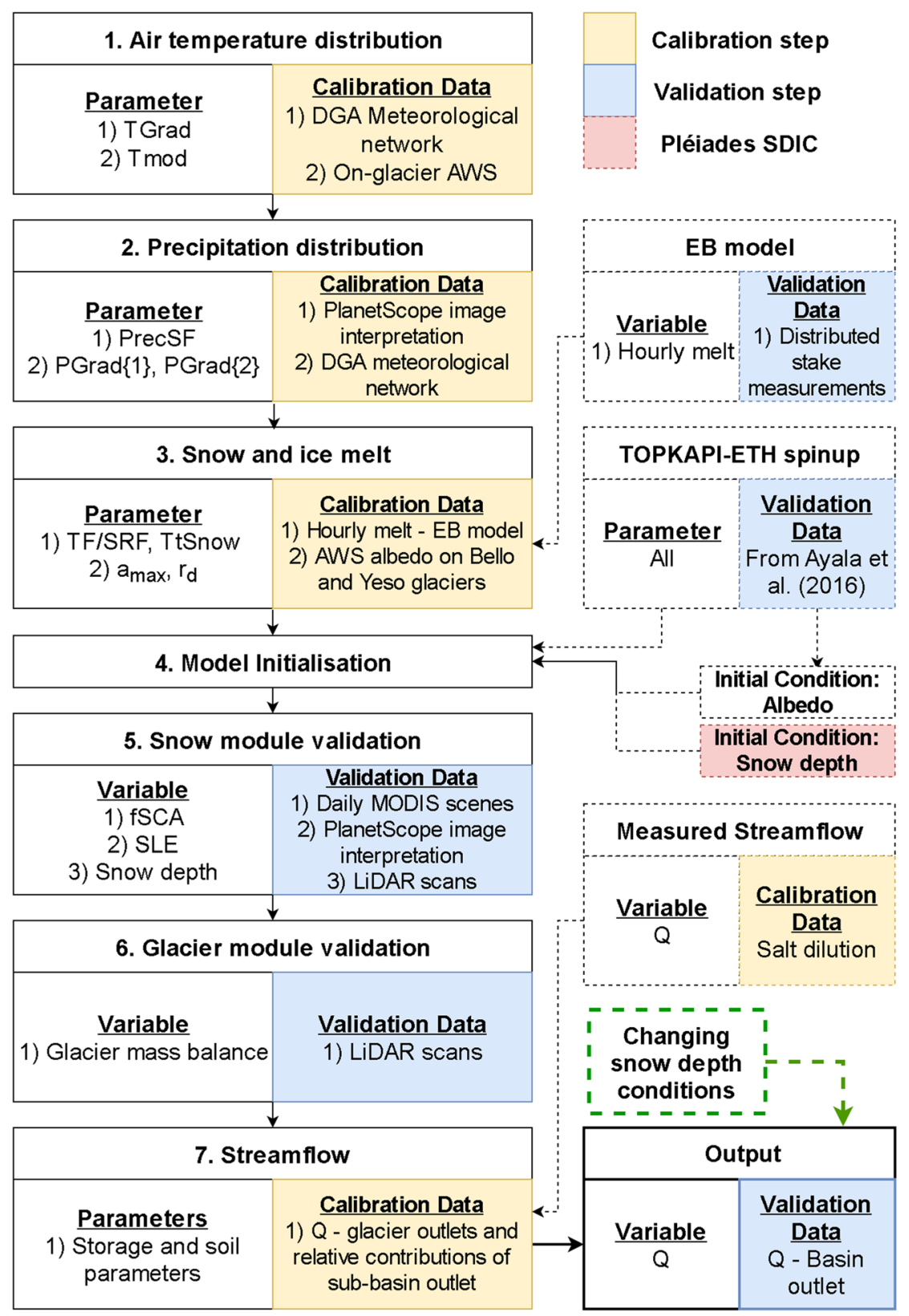

Figure 2. Flowchart for the calibration-validation procedure of TOPKAPI-ETH used in this study. Calibrated values of the model parameters can be found in Table S1 in the supporting information.

\subsection{Mass Balance Data}

Glacier mass balance data were obtained using ablation stakes and scans of a long-range terrestrial LiDAR scanner provided by the "Aguas Andinas" project. Three-meter PVC ablation stakes were installed into all glaciers (Figure 1) at the end of October 2017 using a Heucke steam drill and measured opportunistically during field campaigns in November-December 2017 and March 2018. Surface lowering (with an uncertainty range of $0.05 \mathrm{~m}$ ) was converted to water equivalent melt using locally measured snow density from a snow pit within the LiDAR domain (501 $\mathrm{kg} \mathrm{m}^{3}$ to $4,600 \mathrm{~m}$ a.s.l.), and ice density was assumed to be equal to $900 \mathrm{~kg} \mathrm{~m}^{3}$.

LiDAR measurements of glacier surface change were obtained using a Riegl VZ-6000 at an angular resolution of $0.01-0.02^{\circ}$ (Fischer et al., 2016) in October 2017 and March 2018. The raw point clouds were 
processed in Riegl RiScan Pro software using base-corrected dGPS locations, processed in Trimble Business Center software and stitched together from multiple locations (Figure 1) for each date. Point clouds were manually aligned between different dates based upon common stable features and subsequently registered using automatic cloud-to-cloud registration based upon snow-free bedrock features that are assumed to remain unchanged (Xu et al., 2019). Using these off-glacier locations, we calculated an uncertainty range of $\sim 0.12 \mathrm{~m}$ from the median vertical differencing of rasters in 2-D space. The processed point clouds were rasterized at a $1 \mathrm{~m}$ resolution and adjusted for horizontal and vertical motion as in Shaw, Gascoin, et al. (2020) for comparison to model outputs (section 4.6).

\subsection{Streamflow Data}

Three stream gauges of the "Aguas Andinas" project were installed in the catchment for monitoring streamflow: (i) total basin outflow at Termas del Plomo (F_TdP), (ii) a station before the convergence of rivers from the western valley and that originating from Piramide (F_aP), and (iii) at the outlet of Yeso Glacier (F_Y_Figure 1 and Table 1). Due to a change in the glacier outflow channel, data for F_Y are limited to a short period at the beginning of the melt season for this glacier. Similarly, large gaps in F_TdP were caused by trapped sediment during December-January, 2017/2018. Information on water pressure was recorded every $10 \mathrm{~min}$ and averaged to hourly values. We calculated discharge values from each station individually using salt dilution curves (Moore, 2004) at various stages of the field season and various times of day. We estimated uncertainty of the calculated discharge values $\left(\mathrm{m}^{3} \mathrm{~s}^{-1}\right)$ by comparing variability in dilution curves calculated by a leave-one-out analysis of the available data in each period. From a total of five to six measurements for each location and each period $(n=25)$, we calculated average uncertainties of $13.3 \%$ and $15.2 \%$ for F_aP and F_TdP, respectively.

\section{Methods}

We apply the physically oriented glacio-hydrological model, TOPKAPI-ETH (Topographic and Kinematic Wave Approximation). The model demonstrates an appropriate balance between a conceptual and a full energy balance approach for modeling snow and ice melt, and has shown an adequate performance in many studies within the region (Ayala et al., 2016, 2020; Burger, Brock, \& Montecinos, 2018; Ragettli et al., 2014, 2016; Ragettli \& Pellicciotti, 2012). Following the recommendations of Ragettli and Pellicciotti (2012) and Ayala et al. (2016), we consider a sequential procedure for calibrating and validating the modules of TOPKAPI-ETH with process-specific data (Figure 2). The following subsections summarize the model calibration, initialization, and validation, additional to an evaluation of the relevance of snow depth initial conditions (SDIC) to snowmelt and streamflow estimates. For full details of the model operations and functionality, we refer the reader to Finger et al. (2011) and Ragettli and Pellicciotti (2012).

\subsection{Forcings and Melt Parameters}

We used the temperature and precipitation records of AWS Termas del Plomo (Figure 1) to force TOPKAPI-ETH due to its high elevation (2,995 $\mathrm{m}$ a.s.l.) and representation of local meteorological conditions. Gradients of temperature and precipitation were calibrated using Termas del Plomo and other DGA stations (Table 1), while temperatures over glaciers were estimated based upon the on-glacier AWS records (Figure 1). We calibrated a threshold for solid precipitation based on (i) the distribution of temperature and precipitation records from Termas del Plomo and (ii) the snow line elevation interpreted from PlanetScope images (PlanetTeam, 2018) following each storm event. Using the on-glacier AWS records, we ran a point-based energy balance model following an adaption of Ayala et al. (2017) which was validated against ablation stake records. Using the calculated hourly surface melt rates of this energy balance model, we derived the optimum temperature and shortwave radiation factors (Ayala et al., 2016) using the Kling-Gupta efficiency criterion (KGE; Gupta et al., 2009). Finally, we calculated albedo parameters based upon the algorithm of Brock et al. (2000), using the AWS on Bello Glacier as the median elevation observation for the catchment. For full details, we refer the reader to the supporting information in Texts S1-S3.

\subsection{Model Initialization}

Our best estimate of initial conditions for SWE are snow depth derived by combining the optical tristereo satellite snow depth of Pléiades imagery (section 3.1) and a density map from a distributed blowing snow model (DBSM; Essery et al., 1999). The DBSM model used meteorological information from Termas del 
Plomo AWS and a distributed energy balance routine to derive snow depth (for comparison to Pléiades in this study-section 4.5) and density for the end-of-winter conditions (see Shaw, Gascoin, et al., 2020, for details). Density values agreed with manually measured snow density obtained from field campaigns (RMSE from four samples in the lower catchment on 13 September $2017=20 \mathrm{~kg} \mathrm{~m}^{3}$ ).

Initial soil water storage conditions were provided by a 3 year (September 2014 to September 2017) spin-up model run in all simulations (section 4.5). For the spin-up period, we utilized data from Embalse Yeso AWS (as Termas del Plomo data were available only from March 2017 onward) and the parameters calibrated by Ayala et al. (2016) for this catchment for the period 2012-2015. However, we reassessed precipitation gradients (as described in the supporting information) by including recently collected information.

\subsection{Snow and Glacier Module Validation}

We evaluated the modeled snow covered area by comparison with fSCA from MODIS MOD10A1 and the optical imagery from PlanetScope satellites at selected clear sky dates (section 3.1). The fraction of snow-covered cells was generated from each model time step and assessed using the coefficient of determination $\left(\mathrm{R}^{2}\right)$ and mean bias.

We compared the mean and standard deviation of glacier mass balance derived from TOPKAPI-ETH with observations from the terrestrial LiDAR in elevation bands of $25 \mathrm{~m}$. LiDAR scans for the glaciers were available within the elevation ranges 3,250-3,400 m a.s.l. (Piramide) and 4,000-4,450 $\mathrm{m}$ a.s.l. (Bello and Yeso). Due to large microtopographic variations in the surface of the debris-covered Piramide Glacier causing topographic shadowing in the data, terrestrial LiDAR scans were only able to provide spatially continuous data for the lower ablation zone, and upper zones of the glacier were ignored.

\subsection{Streamflow}

To calibrate soil parameters (Table S1), we followed the approach and plausible ranges described in Finger et al. (2011) and used a Monte Carlo approach to generate 10,000 parameter sets and identified the best parameter set by comparing simulations against streamflow measured at F_aP with the KGE metric. We used F_aP due to its lack of data gaps for the simulation period (Table 1), and utilized the outlet of Yeso Glacier (F_Y) to calibrate the snow storage parameter. Because soil maps were not available for the study site, we constrained the range of possible soil depths by assuming that it decreases with elevation and slope, following Ragettli et al. (2014).

\subsection{Evaluation of Snow Depth Initializations}

We evaluated the benefits of Pléiades-derived snow depths for simulating snowmelt and streamflow by comparing it with alternative estimations of SDIC based on statistical and physically based methodologies. These approaches are described in detail in Shaw, Gascoin, et al. (2020) and briefly summarized here: (i) “TOPO” is a topographic estimation of snow depth derived with the regression equation of Grünewald et al. (2013) and topographic parameters (elevation, northness, and slope angle) obtained from the DEM of the basin. (ii) "DBSM" is snow depth calculated by a distributed mass and energy balance model with a wind redistribution module (Esseryet al., 1999), forced by meteorological information at Termas del Plomo AWS during the preceding winter (May to September 2017), and (iii) "TPK" is the snow depth obtained directly from the 3 year model spin-up period of the TOPKAPI-ETH model routine (section 4.2) with no direct insertion of snow depth. The latter redistributes snow based upon avalanching, though cannot account for wind effects on snow redistribution (as in DBSM). TPK is considered in this study as the control simulation as it would be the standard choice for the modeler if no other data or estimations were available. Benefits to the model based upon the Pléiades SDIC can therefore be compared directly to TPK.

We quantified the added value of Pléiades compared to alternative SDICs examining: (i) the evolution of fSCA throughout the season, (ii) total snowmelt contributions to the soil, (iii) glacier mass balance, and (iv) the timing and magnitude of modeled streamflow. For this, we considered two scenarios: (1) We used the "original" SDIC from each method-that is, where spatial means and distributions of each SDIC are different (as in Shaw, Gascoin, et al., 2020), and (2) we artificially adjusted the alternative methods such that domain-averaged values of SWE are equal with Pléiades, allowing the comparison between SDICs with similar water volumes, albeit with different spatial distributions. The latter scenario allows evaluating the utility of Pléiades for modeling the timing of water availability. We compare the alternative, modeled 


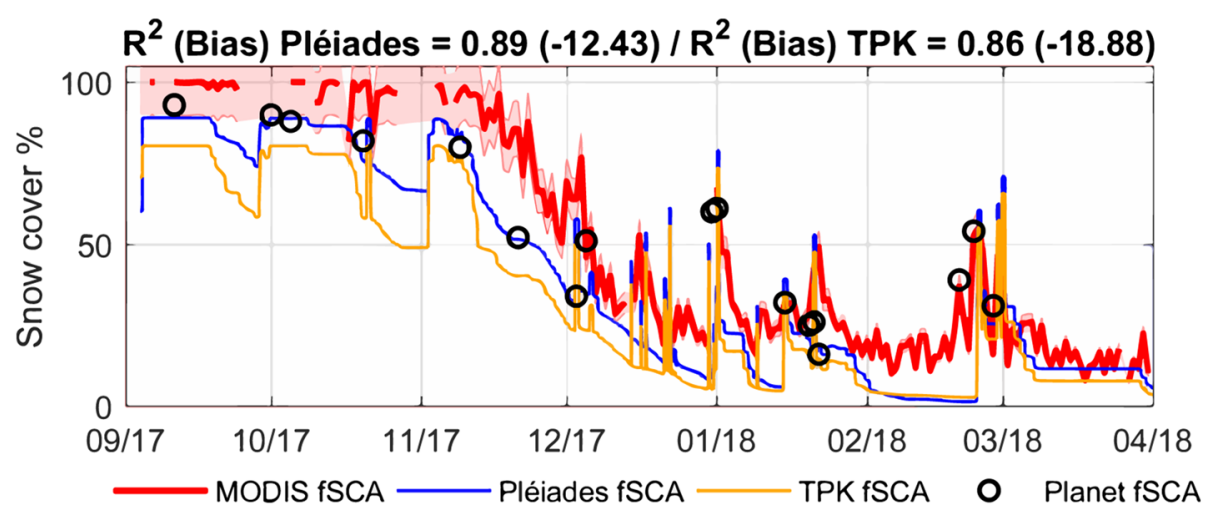

Figure 3. Validation of snow cover evolution throughout the simulation period considering a best estimate model using Pléiades as the snow depth initial condition (blue) and the control model run "TPK" (orange). Modeled (blue and orange) time series of fSCA (\%) are shown against MODIS (red)—assuming a 10\% error estimate (shaded area)—and Planet fSCA (black circles).

SDICs to that of Pléiades, considering the calculated uncertainty of $0.36 \mathrm{~m}$ in the Pléiades SDIC (Shaw, Gascoin, et al., 2020).

\subsection{Sensitivity Experiments}

We tested the model sensitivity to calibrated parameter values of Table S1, additional to the uncalibrated dETI, soil and evapotranspiration parameters, snow density, and forcing uncertainty. We treated precipitation forcing with a $\pm 30 \%$ uncertainty range based upon errors from wind undercatch, wetting, and evapotranspiration (Sevruk et al., 2009) and additional uncertainties that can be associated with sensor errors and drifting of solid precipitation, though not readily quantified in our study. $T_{\mathrm{a}}$ forcing uncertainty was based upon the average of maximum daily differences between aspirated and naturally ventilated air temperature observations on all glaciers between 2013 and 2015 (unpublished data), equal to $\pm 0.5^{\circ} \mathrm{C}$. We applied a snow density uncertainty range of $50 \mathrm{~kg} / \mathrm{m}^{3}$, following Raleigh and Small (2017) who compared the outputs of two empirical (Jonas et al., 2009; Sturm et al., 2010) and two physically based models (Flerchinger \& Saxton, 1989; Marks \& Dozier, 1992) to estimate distributed snow density in the Tuolumne basin, USA. For the remaining parameters, we provided ranges of $\pm 30 \%$ around the optimal (calibrated) or uncalibrated values. We note that a $\pm 30 \%$ range is relatively large, although such arbitrary ranges are typically adopted when a priori ranges of parameters are not available (e.g., Anslow et al., 2008; Ragettli \& Pellicciotti, 2012).

\section{Results}

\subsection{Model Evaluation Using Pléiades}

Following the calibration-evaluation philosophy depicted in Figure 2, we first compare modeled fractional snow cover simulation against PlanetScope and MODIS observations (Figure 3). The Pléiades SDIC simulations reproduce fSCA general dynamics well, capturing the beginning of the spring thaw in late November and the end of the snow season by mid January. Two melt events are seen in the simulations, in early October and in the first half of November, but these are not reflected in the MODIS product, and are not observed by the PlanetScope observations given its clear sky overpass dates. Both Pléiades and TPK simulations underestimate fSCA as indicated by MODIS throughout the modeling period, though differences with MODIS may be expected, given that the complex terrain predominant in this catchment is likely to affect the representativeness of the coarse-resolution product. The simulation better matches the PlanetScope observations when initializing the model with the satellite-based snow depths (Pléiades). The TPK model control simulation under-estimates the catchment fSCA by up to 15-20\% during October to November, compared to the Pléiades SDIC simulation and results in a smaller $\mathrm{R}^{2}$ and greater bias (Figure 3).

Where available, glacier mass balance observations match well the model estimates derived from Pléiades direct insertion (Figure 4). LiDAR observations in the Piramide glacier are restricted to lower elevations and obscured by topographical features in the debris-covered surface, so we are unable to assess the 


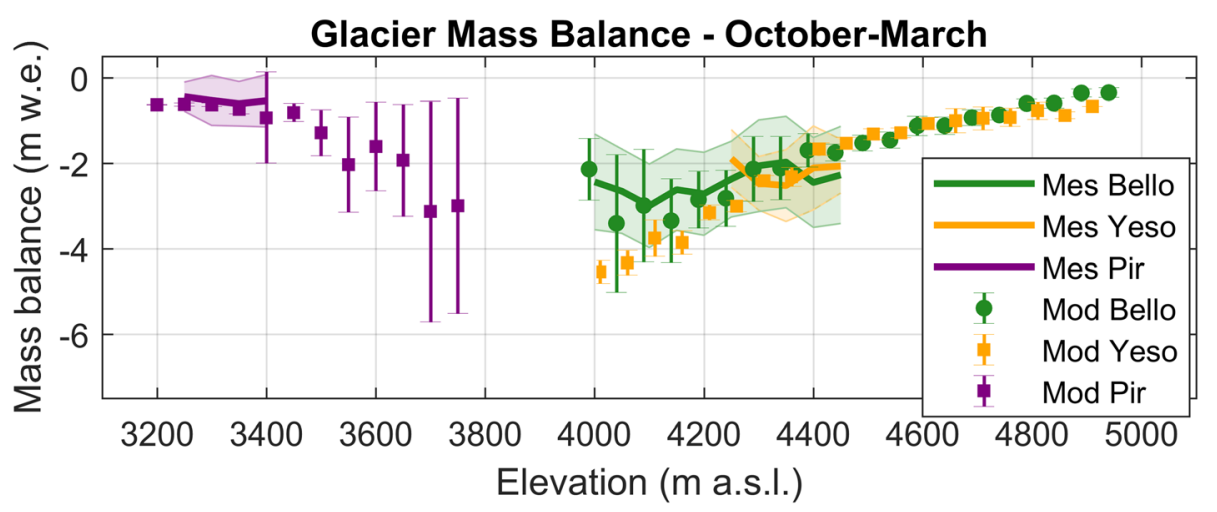

Figure 4. Elevation-averaged glacier mass balance. Error bars represent modeled means (points) and standard deviations (whiskers) by $50 \mathrm{~m}$ elevation increments, whereas bold lines and shaded areas indicate the respective means and standard deviations of the LiDAR measurements.

realism of the estimates at higher elevations for that glacier. Also, we note that LiDAR mass balance shows a degree of heterogeneity not captured by the simulations. This results from a relatively simple ablation modeling scheme adopted by TOPKAPI-ETH, which is strongly determined by air temperature variability (that in turn is modeled here as elevation-dependent). Nevertheless, the average mass balance is closely matched by the simulations at the Piramide glacier. Similar skill can be seen when simulating mass balance at the Bello glacier (observations available in the 4,000-4,450 $\mathrm{m}$ a.s.l. band), although the spatial variability is better captured here. Observations at the Yeso glacier are too sparse to evaluate a general trend in model skill, although a $\sim 0.2 \mathrm{~m}$ w.e. bias is observed where LiDAR mass balance measurements are available.

Hourly modeled streamflow at both F_aP and F_TdP locations generally agree with the observations (KGE of 0.64 and 0.67 for F_aP and F_TdP, respectively, Figure 5), whereby TOPKAPI-ETH captures seasonal variability and change driven by cooling and solid precipitation events. Modeled streamflow at F_aP underpredicts the occurrence of high flows generated by suspected heavy liquid precipitation events during December (Figure 5a) and fails to match maximum daily values (Figures 5a and 5c) despite replicating the minimum and mean daily variations. Conversely, maximum daily streamflow at F_aP is slightly overestimated during early February, whereby the majority of melt is derived from glacier ice. Total streamflow of the simulation period from F_aP is overestimated by $<2 \%\left(\sim 2.9 \times 10^{5} \mathrm{~m}^{3}\right)$, which is within the uncertainty of measurements (section 3.4). In total, streamflow at F_TdP is overestimated by $\sim 5 \%$, though the measurement record is subject to larger data gaps. At this site, the model is more likely to overestimate observed flow, particularly above $2 \mathrm{~m}^{3} \mathrm{~s}^{-1}$, which in the observed data are concentrated in late February, when almost all flow in the basin is glacier-originated. The average simulated contribution of glacier ice melt to total streamflow at F_TdP is $44 \%$ during the study period.

\subsection{Relevance of Snow Depth Initial Conditions}

Figure 6 shows spatial differences in snow water equivalent simulated with alternative SDICs relative to the model results with the Pléiades SDIC, for three winter-spring time steps. The largest differences are those corresponding to the topography-only-based distribution (TOPO), which for high-elevation zones overestimates respectively to Pléiades by up to $500 \mathrm{~mm}$ w.e. in places. Likewise, for the control model ("TPK"), the dependency of snow depth on elevation results in excessive accumulation and persistence of snow at the highest elevations, forming large accumulations within avalanche cones, (Figure 6n). DBSM-derived SWE estimate lacks the spatial complexity of SWE distribution observed from Pléiades (Figure 6b) but retains the spatial pattern of over estimation and underestimation seen in the TPK simulation, with the exception of the areas over the Piramide glacier and near the basin outlet, where it overestimates SWE relative to Pléiades. Figure 7 summarizes these results by summing SWE over elevation bands. It can be seen that DBSM, Pléiades, and TOPO share common traits in terms of SWE variability, whereas the TPK distribution is significantly more skewed toward the higher-elevation zones of the catchment, most likely due to the inability of the TOPKAPI-ETH to redistribute snow through wind and sloughing. 

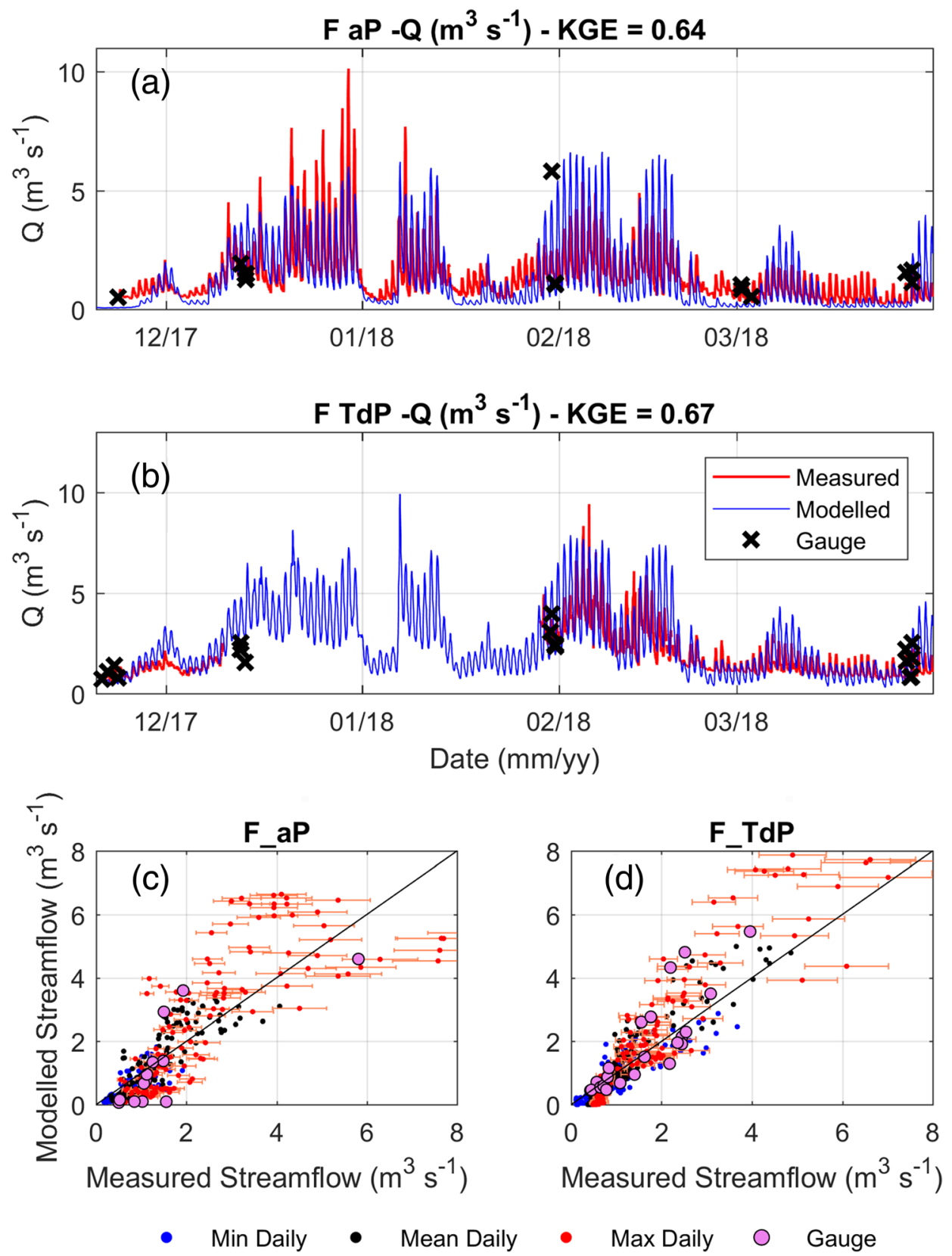

Figure 5. Measured and modeled discharge at stations F_aP and F_TdP between November and March (panels a and b) with specific gauging measurements indicated by the black crosses. Panels (c) and (d) show the measured and modeled minimum (blue), mean (black), and maximum (red) daily values and salt dilution gauge measurements (purple dots). Horizontal error bars for the maximum daily values reflect mean measured streamflow errors for the respective stations. Error bars for minimum and mean observations are not plotted for neatness. We define the "gauge" measurements as the manual, in-field measurements and "measured" streamflow as that calculated using the salt dilution curves.

The contribution of each SDIC to total catchment snowmelt varies widely, especially for TOPO, which is approximately double that of Pléiades (Figure 8). TPK under-estimates the total snowmelt of the catchment by $\sim 25 \%\left(0.35 \times 10^{4} \mathrm{~m}\right.$ w.e. $)$, and DBSM performs similarly to Pléiades. When normalizing all SDICs alternatives to the same catchment-wide mean (dashed lines), the runoff contributions of Pléiades, TOPO, and DBSM all reduce to differences within $1 \%$ of each other. TPK, on the other hand, yields a much smaller snowmelt estimation, because of its skewed SWE elevation distribution (Figure 7) and the influence of temperature on the melt equation within the model. 


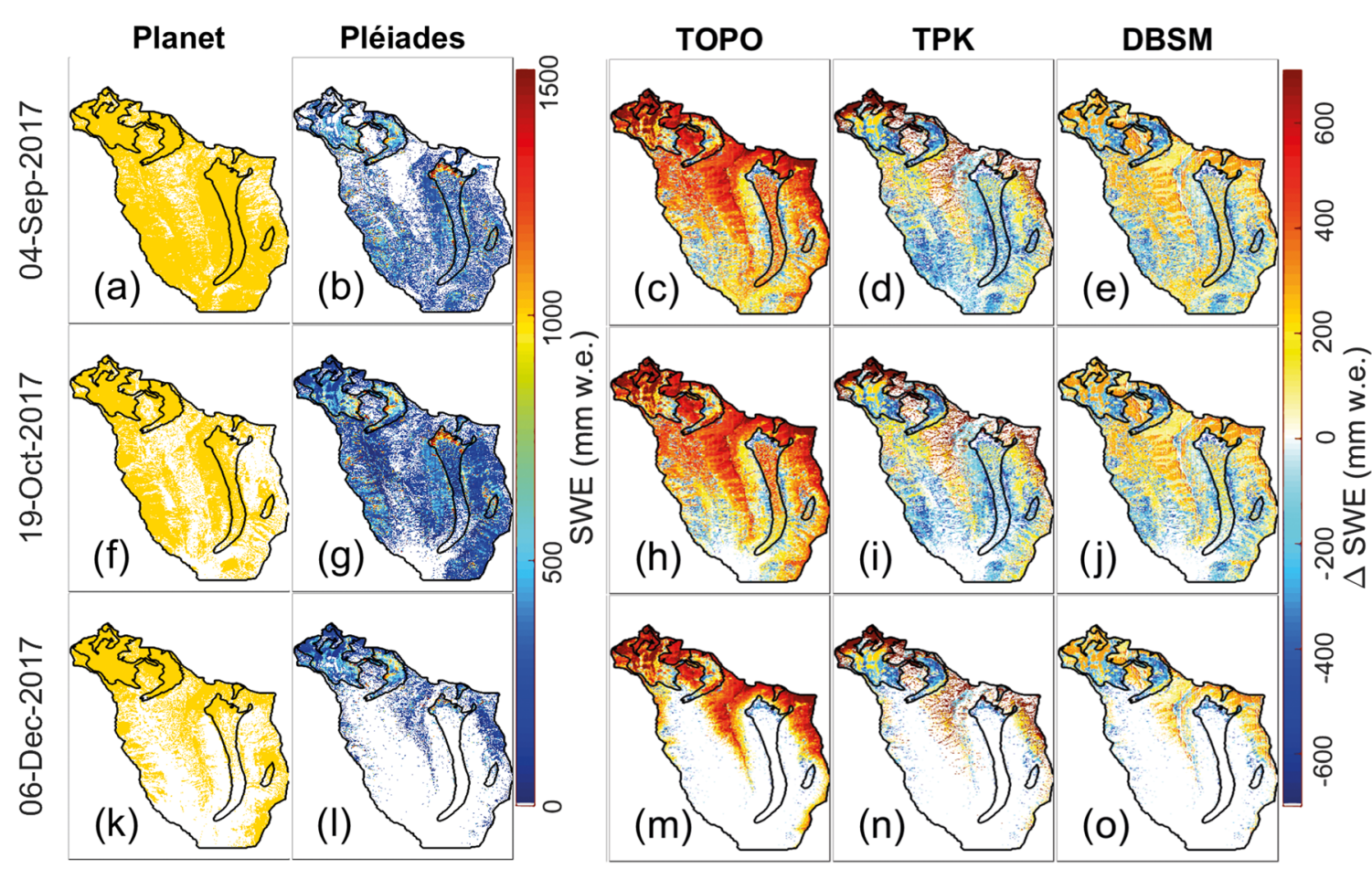

Figure 6. Planet snow cover (a, f, and k) and Pléiades SWE (b, g, and l) maps of the model basin at three winter-spring time steps and relative SWE maps of the TOPO (c, h, and m), TPK (d, i, and n) and DBSM (e, j, and o) compared to Pléiades at the same time steps. All color scales are equal for Pléiades SWE (0-1,500 mm w.e.) and SDIC relative SWE ( -600 to $+600 \mathrm{~mm}$ w.e.) plots. Panel (b) is the Pléiades-derived SDIC for model initialization (i.e., $t=1$ ).

04-Sep-2017

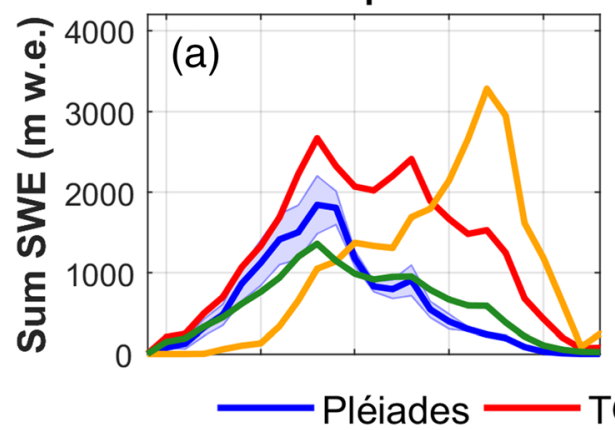

06-Dec-2017

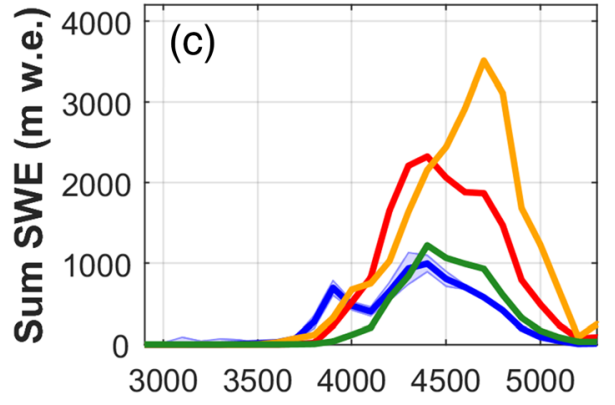

19-Oct-2017

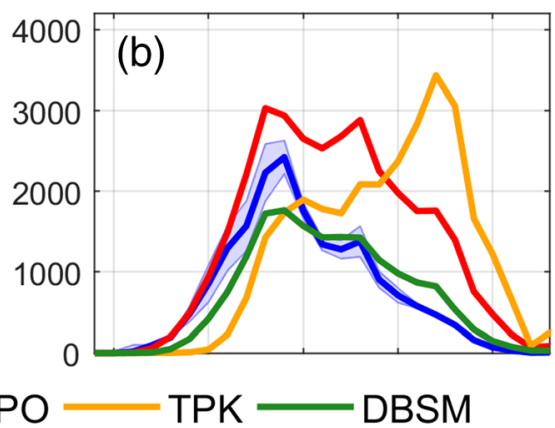

31-Mar-2018

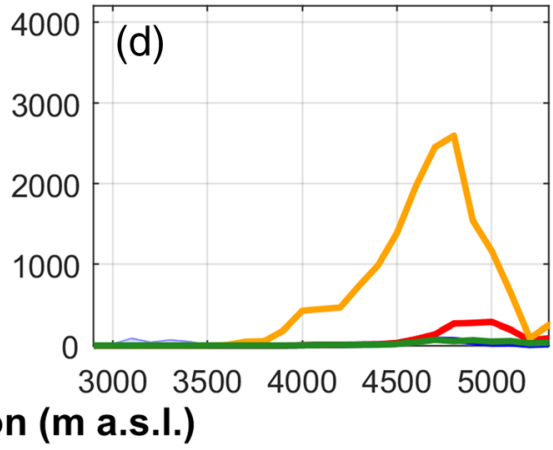

Figure 7. Summed SWE-elevation plot (as Figure 3) for the time steps given in Figure 6 (and the end of the model study period). Plotted are Pléiades (blue) with observation uncertainty in the shaded area and the original SDIC model runs. (a) 4 Sep 2017; (b) 19 Oct 2017; (c) 6 Dec 2017; (d) 31 Mar 2018. 


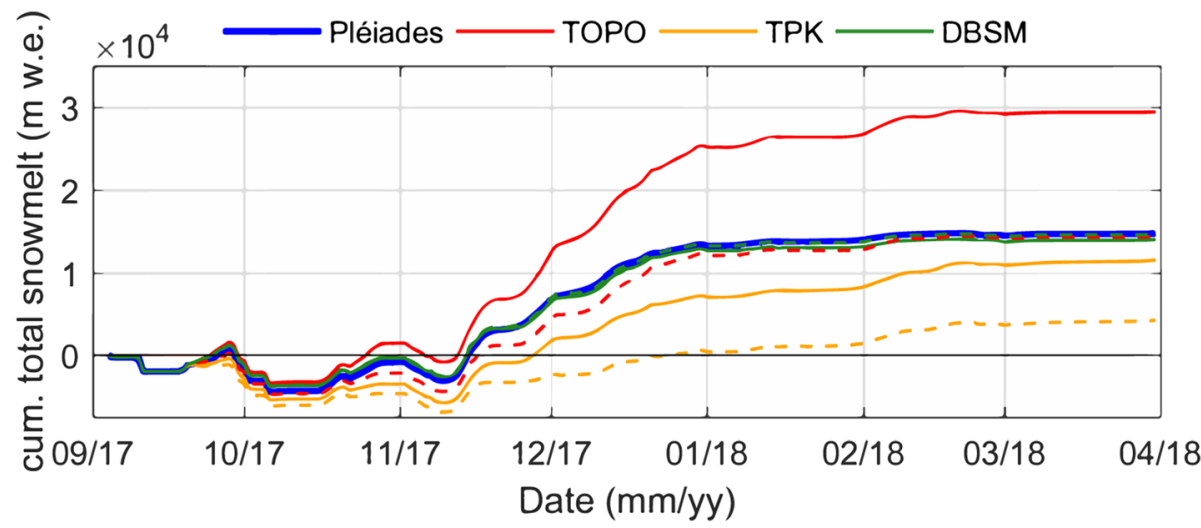

Figure 8. The cumulative total snowmelt (m w.e.) for the model study period, where dashed lines are the equal means alternatives of SDIC.

Average glacier-wide mass balance differences are subtle (Table S2), though distributed differences are more indicative of the importance of distributed snow depth in the catchment (Figure 9). Mass balances for all alternative models are higher on the upper Bello Glacier (Figures 9b-9d), due to snow transport by wind evident in Pléiades observations, which lowers surface albedo (mass balances between 0.1 and $0.45 \mathrm{~m}$ w.e. more negative). More uniform snow cover for TOPO and DBSM resulted in more positive mass balances for Piramide Glacier compared to Pléiades, and all alternatives experienced less negative mass balance for the upper Piramide Glacier due to a smaller accumulation and ablation of winter snow (Figure 6).

TOPO consistently overestimates observed streamflow at F_aP, with a total difference $>10 \%$ for the study period, whereas TPK and DBSM report similar underestimation of total streamflow to that of Pléiades (Figure 10a). Nevertheless, TPK and DBSM SDICs achieve this total small bias by compensating stronger underestimation and overestimation of measured streamflow during January and February, respectively (Figure 10a), amplifying the seasonal model errors already inherent from the forcings and calibrated parameters (Figure 5). Pléiades and TPK provide a better estimate of streamflow timing, while TOPO achieves a lower relative variance, but also a lower correlation and greater bias (Figure S2). Considering equal means

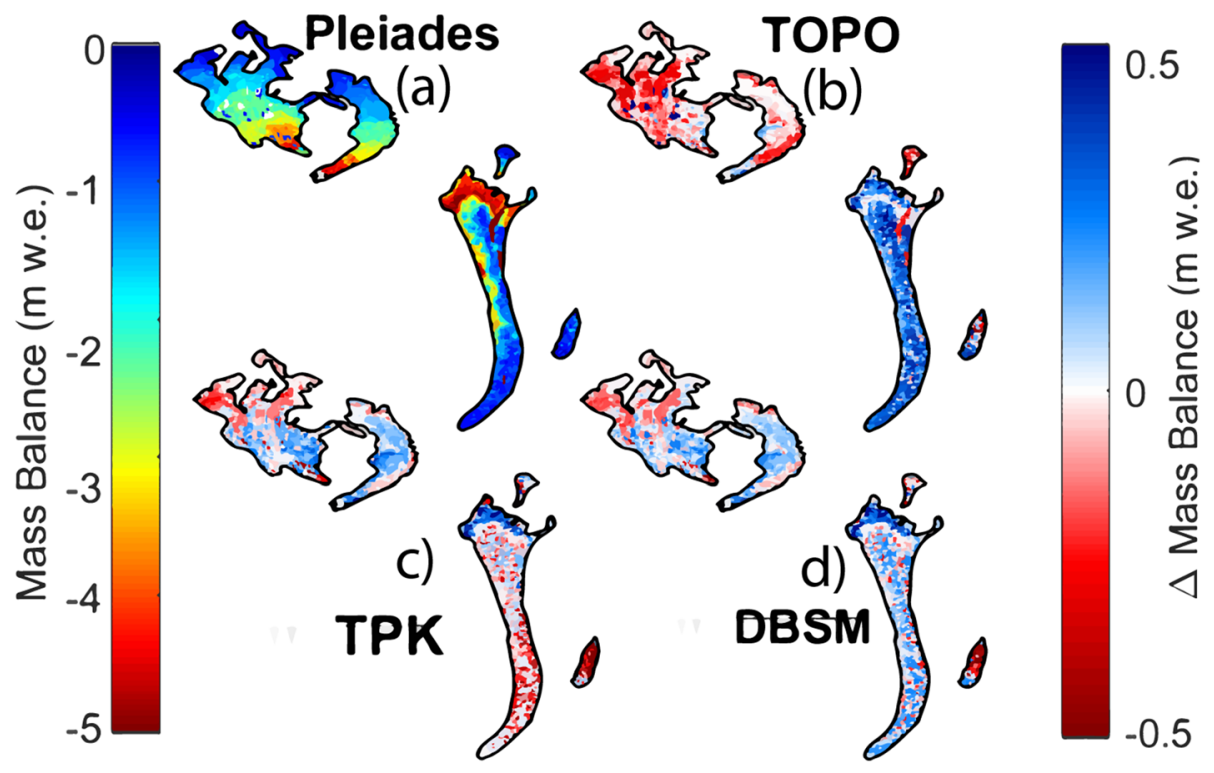

Figure 9. Distributed modeled glacier mass balance ( $m$ w.e.) considering Pléiades SDIC (a) and the relative differences of modeled glacier mass balances considering a TOPO (b), TPK (c) or DBSM (d) SDIC. Color scales for (b)-(d) are equal. 


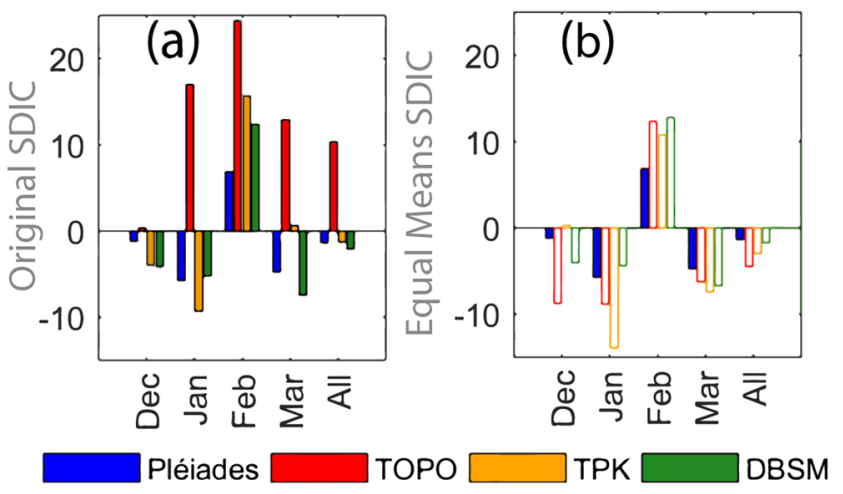

Figure 10. Relative differences in total streamflow for station F_aP (a) in individual months and for the complete simulation period for SDICs compared to the observations. Panel (b) as in (a) but for the equal means approaches (hollow colored bars). of alternative SDICs, metrics remain similar (Figure S2), but both TOPO and TPK result in larger underestimations of measured streamflow compared to their original SDICs (Figure 10b).

\subsection{Model Sensitivity Analysis}

The one-at-a-time sensitivity of catchment streamflow simulated by our best estimate model (Pléiades SDIC and calibrated parameters) to parameter and forcing perturbations is shown in Figure 11. Considering the total streamflow of the catchment $\left(F_{-} T d P\right)$ relative to the best estimate model over the entire simulation period (Figure 5), the choice of SDIC is much less sensitive to that of several parameters or forcing uncertainties, being only the ninth most sensitive element on average (maximum difference of different SDICs are shown). In general, model sensitivities are dominated by uncertainties in air temperature (Ta forcing (f) and "TGrad") and those that control shortwave radiation ("Albedo" and "SRF"). However, for the early spring months (September to November), the choice of SDIC can affect the total streamflow of the catchment more than most other parameters/forcings (a sensitivity of up to $-48 \%$ compared to the best estimate model). Nevertheless, in absolute terms, the sensitivity of the model to the choice of SDIC produces smaller overall differences than uncertainty in temperature or SRF, especially for summer months (January to March), when absolute streamflow is larger. In all cases, snow depth is found to be more important for modeled runoff estimates than density and, during certain months, more sensitive than precipitation forcing ("P(f)" or "PGrad").

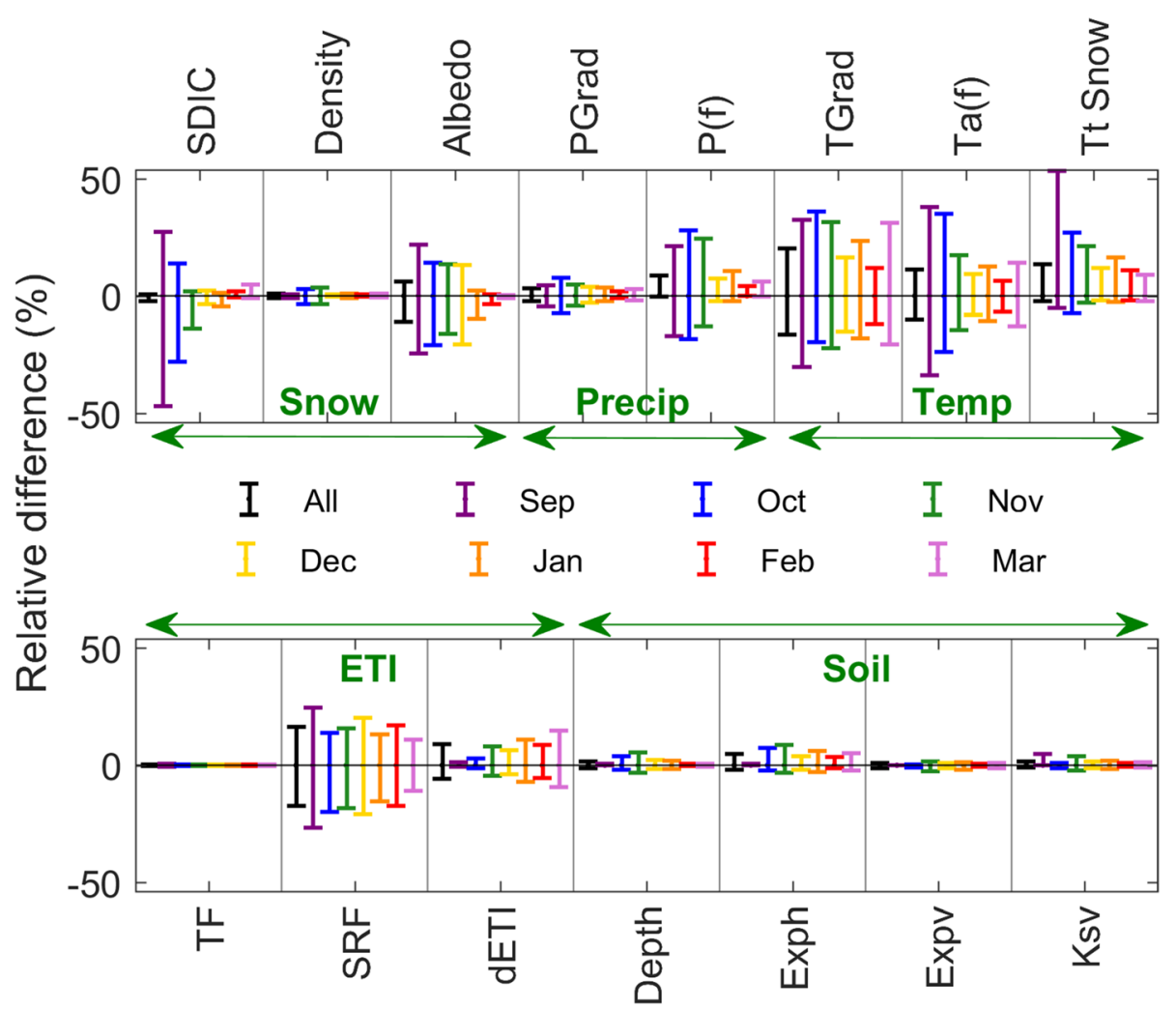

Figure 11. The relative catchment streamflow difference (F_TdP) compared to the best estimate model (Pléiades SDIC and calibrating forcings/parametersFigure 5) from a one-at-a-time factor perturbation, displaying grouping of parameter types by the whole period (black) and individual months (colored bars). The positive differences indicate greater total streamflow for F_TdP compared to the best estimate model, and vice versa. Only the most sensitive of soil parameters are shown in the figure for neatness. The SDIC sensitivity shows the largest deviations from Pléiades between the alternatives SDICs presented. 


\section{Discussion}

\subsection{Relevance of Snow Depth Initial Conditions for Glacio-Hydrological Modeling}

Shaw, Gascoin, et al. (2020) found large differences in spatial snow depths derived from Pléiades satellites when compared with estimations from statistical or physically based models that used local, high-elevation data. The work presented here demonstrates that this high-resolution satellite information is useful for improving the spatiotemporal representation of snowpack (Figures 3 and 9), and the seasonality of catchment streamflow (Figures 5 and 10a) when used as an initial condition for a physically oriented glacio-hydrological model.

Our results demonstrate that differences in the spatial representation of snow depth can lead to large variations in modeled seasonal streamflow (i.e., between 5\% and $48 \%$ during individual months - Figure 11) due to the convolution in time of energy inputs and available snow (Figure 8). We corroborate previous findings (Jonas et al., 2009; López-Moreno et al., 2013; Painter et al., 2016) by showing that spatial uncertainty of snow depth is more influential for streamflow modeling than the spatial uncertainty related to snow density (approximately twice as sensitive on average in this study). We acknowledge that density is largely unknown and is based here upon model estimations that are not necessarily appropriate for the derived depths (e.g., that physical processes considered in DBSM do not explicitly reflect the "real" snow conditions shown by Pléiades). However, we find that if we derive densities based upon snow depth following the approach of Jonas et al. (2009), that total modeled streamflow differed only by $\sim 3.5 \%$.

We found that a simple approach to estimate snow depth based upon regression with topographic parameters (TOPO) overestimates total SWE (Figure 3), fSCA, snowmelt contributions (Figure 8), low-elevation glacier mass balance (Figure 9 and Table S2) and streamflow in all months of the study period (Figure 10) when compared to observations. This statistical approach was derived from topographic parameters of snow observations for sites in Canada and Europe (Grünewald et al., 2013), and although we used local data to calibrate absolute values for our catchment (see Shaw, Gascoin, et al., 2020), the approach produces very high SWE for high elevations. We applied the coefficients from the study of Grünewald et al. (2013) due to the lack of similar coefficients for the Andes and to avoid utilizing Pléiades data for any alternative SDICs. Nevertheless, generating new statistical regression relationships of snow depth may be afforded by existing and future Pléiades data and used for calibrating future SDIC estimations in this catchment. For example, Shaw, Gascoin, et al. (2020) demonstrated that snow depths derived from Pléiades were also strongly related to catchment elevation, though orientation relative to north and exposure (the latter not considered by TOPO) were also important factors for determining snow depth.

The TPK SDIC is deemed as the model control in our study, in that it would likely be the choice made by a modeler in the absence of other initial conditions. TPK, however, provided an inherent overaccumulation on high-elevation, steep terrain, where avalanching was not fully simulated and wind effects neglected (Ayala et al., 2020). This is largely the result of model limitations (i.e., no wind transport and dependency on model resolution), though likely also due to localized meteorological conditions. Temperature gradients used to extrapolate air temperature from a lower-elevation AWS (Embalse Yeso) in the spin-up period were clearly insufficient to prescribe an appropriate end-of-winter snow line elevation and snow depth, especially using precipitation phase thresholds based upon previous work (Ayala et al., 2016). Because the simulation of snow remobilization (through wind or avalanching) is an inherently complex process to model and dependent upon several unknowns (e.g., air temperature and precipitation distribution), replacing this computational complexity with high-resolution SDIC data from Pléiades is highly advantageous in the context of glacio-hydrological modeling.

We demonstrate that the most similar hydrological responses to those obtained from Pléiades were produced when using the DBSM model initialization (Figures 8 and 10), which calculated the energy balance and snow accumulation/re-distribution during the 2017 austral winter (Shaw, Gascoin, et al., 2020). This SDIC assumed a precipitation gradient similar to that suggested in the literature for this region (Burger, Brock, \& Montecinos, 2018; Ragettli et al., 2014), though calibrated locally using newly available, high-elevation precipitation data (Termas del Plomo). It is clear that this approach cannot replicate the spatial variability of the Pléiades snow depth observations, resulting in a sequence of overestimation and underestimation (Figure 6e). This stems from a combination of precipitation observations only at relatively low elevations for the catchment (vertical differences up to 2,400 m) and wind fields that are unable to appropriately 
redistribute snow in the DBSM model routine (i.e., on Bello Glacier, Figure 9d). Interestingly, given the similar elevation distributions of total SWE from the DBSM SDIC (Figure 7), we find similar contributions of total snowmelt (Figure 8) and total subcatchment streamflow differences (Figure 10), within the uncertainty of the measurements. This suggests that, with enough local observations or good enough atmospheric models of air temperature, precipitation and wind speed/direction to constrain it, DBSM could provide a generalized estimate of total SWE for modeling catchment streamflow. However, the sparse data availability in this region, combined with potential measurement uncertainties of high-elevation precipitation again emphasize the utility of remotely- sensed information for deriving snow depth initial conditions.

\subsection{Limitations of Study}

Given the relatively large ratio of elevation range to total area of our study catchment compared to those where extensive snow depth surveys have been previously conducted (e.g., Painter et al., 2016), we find that the timing and magnitude of streamflow are largely influenced by elevational-dependent air temperature variability and shortwave radiation throughout the season (consistent with the findings of Li et al., 2009). Therefore, when comparing snowmelt contributions, glacier mass balance, and fSCA, we observe the importance of SDICs (Figures 8 and 9), though model simplifications, soil parameter unknowns and forcing uncertainties (Figure 11) partly obscure the true value of an accurate SDIC to hydrological responses in our central Andean study catchment. Lack of wind transport and static parameters for boundary layer temperature adjustment ("TMod"), melt and albedo that were calibrated against single in situ observations, oversimplify the representation of snow energy balance, which will also be more variable given the different initial conditions. For example, dependency of the albedo parameterization (Brock et al., 2000) on temperature and time since fresh snowfall means that parameters for modeling snowmelt are very elevation dependent. Hence, a single parameter value for a median elevation observation (AWS on Bello Glacier) is likely to underestimate (overestimate) albedo decay at lower (higher) elevations, simplifying the catchments response to complex distributions of SWE. Even so, we note that these sparse observations are often the required choice for calibrating parameters for sizeable basins (Ragettli \& Pellicciotti, 2012; Ragettli et al., 2015; Stigter et al., 2017) and we consider the application of TOPKAPI-ETH a useful compromise between physical complexity and computational resources to model local cryospheric processes in more detail.

A key limitation of our study is reliance upon a single snow depth map at the beginning of September which is deemed as an "end-of-winter" estimate of SWE. However, subsequent early spring (October) snowfall events have partially obscured the relevance of the Pléiades SDIC for replicating observed snow cover evolution (Figure 8a) and suggest that multiple snow depth maps would be ideal to capture the variability of snow depth during spring (Belart et al., 2017; Hedrick et al., 2018), that is inherently difficult to simulate (Figure 6). Hedrick et al. (2018) utilized the Airborne Snow Observatory (LiDAR) data (Painter et al., 2016) for direct insertion into an energy balance routine at a $50 \mathrm{~m}$ resolution in the Tuolumne Basin, USA. Their study found a dramatic improvement in model performance for SWE estimation when updating the model routine with LiDAR data on several dates. Nevertheless, Margulis and Fang (2019) and Li et al. (2019) found that leveraging single midseason snow depth maps can substantially improve estimation of SWE and snowmelt, finding similar large deviations in SWE to our study when applying a single snow depth map from Pléiades observations.

\subsection{Future Applicability of Pléiades for Initial Conditions}

Pléiades snow depths have several advantages in initializing our glacio-hydrological model compared to the control case (TPK) as (i) it can realistically update the model simulation (spin-up) to replicate trends in snow cover area derived from high-resolution daily satellite imagery (Figure 3), (ii) modeling the timing and monthly magnitudes of snowmelt and streamflow can be improved (Figure 10), (iii) reliable data can build confidence in calibration of other, related elements of the modeling process, such as snowmelt or soil parameters, and (iv) intensive field campaigns can be potentially avoided to collect the necessary data for snow distribution or calibrating model estimates.

We recognize that we present a highly constrained model of a relatively small catchment in one season, with a large series of calibration/validation steps that may not always be possible given the lack of ground-based data at high elevations. However, in our case study we are able to limit, to some degree, uncertainties within parameters that govern ablation and hydrologic processes through sequential calibration (Figure 2) using 
various in situ or satellite observations (Figure 1). We find, that with a combination of ground-based (i.e., LiDAR) and satellite observations at high spatial and temporal resolutions (PlanetScope), we are able to calibrate individual processes with more control and prevent a bulk calibration of plausible parameters against only one or two sources of observations (i.e., soil and snow parameter sets against MODIS and streamflow, respectively-(Finger et al., 2011; Shrestha et al., 2015)). In this respect, we have confidence that several of the individual processes, such as snow retreat or glacier mass balance, are modeled appropriately and that intercomparisons regarding the relevance of snow depth initial conditions can be more robustly assessed.

We show that coarse-resolution SDICs from energy balance modeling (DBSM), while smoothing the complex spatial variability in SWE (Figure 6e), match general trends of total SWE with elevation (Figure 3) that ultimately govern snowmelt and total streamflow through control of elevation-dependent temperature variations and albedo (Figures $8 \mathrm{~b}$ and 10a). However, we recognize that our study catchment represents only $\sim 2 \%$ of the total Maipo river catchment (Shaw, Gascoin, et al., 2020). Modeling larger domains with alternative methodologies for snow depth derivation (e.g., TOPO, DBSM, or other alternatives) are likely to produce even greater differences in total SWE compared to high-resolution satellite observations, especially where dependence upon elevation (TOPO) or uncertainty in the distribution of forcing variables (TPK/DBSM) are augmented. For example, modeling elevation trends in total SWE (as DBSM generally achieves) would likely be more difficult over larger basin areas with greater elevation ranges because it combines the increased uncertainty in total precipitation, statistical precipitation/ temperature gradients ("P/TGrad"), and the modeling of storm origins that are all dependent on highly localized observations.

We therefore consider that SDICs derived from DEM differencing of high resolution optical satellites offer a practical solution to reduce uncertainties in initial conditions, which would be valuable when upscaling glacio-hydrological modeling in the central Andes. This is especially true due to the high temporal revisit period (daily) of the Sun-synchronous satellite pair (Marti et al., 2016) and the relatively clear sky conditions during winter compared to other mountain regions of the world ( 70\% clear sky winter days (May to September) between 2016 and 2020-unpublished data). For other regions, cloudy conditions may be a more limiting factor for obtaining imagery for the "ideal" date. Obtaining several Pléiades DEMs during the "endof-winter" and early melt season (Belart et al., 2017; Hedrick et al., 2018) or single, "well-timed” observations to capture peak SWE (Margulis \& Fang, 2019) for larger areas would be especially beneficial to the advancement of this work.

\section{Conclusions}

We apply observations of detailed spatial snow depth from Pléiades satellites as an initial condition for a glacio-hydrological model of a high-elevation Andean catchment. Utilizing a wide variety of local ground-based and satellite observations, we are able to confidently calibrate the model parameters to represent several of the localized cryospheric processes occurring in the basin (i.e., glacier mass balance and snow cover evolution) and examine the relative importance of snow depth initial conditions compared to other model parameter and forcing sensitivities.

We find that skewed distributions of spatial snow depth from alternative initial conditions estimations or a model control without snow depth insertion can produce differences in early spring streamflow up to $48 \%$ and decreased performance in estimating the magnitude of snow melt and snow cover area in comparison to using Pléiades for initial conditions. Snow depth initial conditions derived from energy balance calculations lack the spatial complexity of Pléiades observations, though can reproduce total snowmelt and streamflow, due to the elevation distribution of total snow water equivalent and the dominant role of air temperature variability for hydrological response. However, all alternative initial snow conditions require appropriate estimates of total catchment snow volumes which are hard to derive without spatially representative, high-elevation observations that are seldom available. Upscaling these alternative initial condition approaches for larger domains will also likely introduce a greater uncertainty of unconstrained temperature/precipitation forcing to which the methods are highly sensitive. Therefore, Pléiades offers an advantage for obtaining detailed spatial snow depths that aid (i) modeling both the timing and quantities of streamflow, (ii) process representation and reduced uncertainty regarding the calibration of related snowmelt or (potentially) soil parameters, and (iii) spatial representation not afforded by costly ground/airborne 
campaigns. We recommend the application of the optical satellite stereo-photogrammetry (Pléiades, World-View 3, etc.) to generate snow depths for larger domains where deviations between alternative estimations of snow depth may be greater still.

\section{Conflict of Interest}

We confirm that there are no conflict of interest in the submission of this work.

\section{Acknowledgments}

This work recognizes funding from FONDECYT projects 3180145 (T. E. Shaw), 1171032 (J. McPhee), 3170079 (P. Mendoza), and 3190732 (A. Ayala) as well as equipment and field work support by project "Estudio del aporte glaciar en la cuenca del río Maipo," developed by Cetaqua/Untec for Aguas Andinas, Sociedad del Canal de Maipo y Junta de Vigilancia del río Maipo. Fieldwork was supported by S. Quezada, B. Mir, S. Barros, J. Venegas, E. Aldunate, Y. Videla, and M. Huerta. AWS and flowmeter stations used in the "Estudio del aporte glaciar en la cuenca del río Maipo" were provided by Latina UC and the research group of C. Oberli. This work has been supported by the CNES Tosca and the Programme National de Télédétection Spatiale (PNTS, http://www.insu.cnrs.fr/pnts), Grant PNTS-2018-4. Forcing data, model grids, initial condition maps, parameters, and model run files are provided in the following repository: https://zenodo.org/record/3613951\#. XiYSKkaJKUk (doi:10.5281/ zenodo.3613951, cited as Shaw, Caro, et al., 2020). We thank scientific editor J. Lundquist and two anomymous reviewers for the valuable comments that improved the quality of the manuscript.

\section{References}

Alvarez-Garreton, C., Mendoza, P. A., Boisier, J. P., Addor, N., Galleguillos, M., Zambrano-bigiarini, M., et al. (2018). The CAMELS-CL dataset: Catchment attributes and meteorology for large sample studies-Chile dataset. Hydrology and Earth System Sciences, 22(11), 5817-5846. https://doi.org/10.5194/hess-22-5817-2018

Anslow, F. S., Hostetler, S., Bidlake, W. R., \& Clark, P. U. (2008). Distributed energy balance modeling of South Cascade Glacier, Washington and assessment of model uncertainty. Journal of Geophysical Research, 113, F02019. https://doi.org/10.1029/2007jf000850

Armstrong, R. L., Rittger, K., Brodzik, M. J., Racoviteanu, A., Barrett, A. P., Khalsa, S. S., et al. (2019). Runoff from glacier ice and seasonal snow in High Asia: Separating melt water sources in river flow. Regional Environmental Change, 19(5), 1249-1261. https://doi.org/ 10.1007/s10113-018-1429-0

Avanzi, F., Bianchi, A., Cina, A., De Michele, C., Maschio, P., Pagliari, D., et al. (2018). Centimetric accuracy in snow depth using unmanned aerial system photogrammetry and a multistation. Remote Sensing, 10(5), 765. https://doi.org/10.3390/rs10050765

Ayala, Á., Farías-Barahona D., Huss M., Pellicciotti F., McPhee J., Farinotti D. (2020). Glacier runoff variations since 1955 in the Maipo River basin, in the semiarid Andes of central Chile. The Cryosphere, 14(6), 2005-2027. https://doi.org/10.5194/tc-14-2005-2020

Ayala, A., Pellicciotti, F., Macdonell, S., Mcphee, J., Vivero, S., Campos, C., \& Egli, P. (2016). Modelling the hydrological response of debris-free and debris- covered glaciers to present climatic conditions in the semiarid Andes of Central Chile. Hydrological Processes, 30(22), 4036-4058. https://doi.org/10.1002/hyp.10971

Ayala, A., Pellicciotti, F., Peleg, N., \& Burlando, P. (2017). Melt and surface sublimation across a glacier in a dry environment: Distributed energy-balance modelling of Juncal Norte Glacier, Chile. Journal of Glaciology, 63(241), 803-822. https://doi.org/10.1017/jog.2017.46

Baba, M., Gascoin, S., Jarlan, L., Simonneaux, V., \& Hanich, L. (2018). Variations of the snow water equivalent in the Ourika Catchment (Morocco) over 2000-2018 using downscaled MERRA-2 data. Water, 10(9), 1120. https://doi.org/10.3390/w10091120

Bales, R. C., Molotch, N. P., Painter, T. H., Dettinger, M. D., Rice, R., \& Dozier, J. (2006). Mountain hydrology of the western United States. Water Resources Research, 42, W08432. https://doi.org/10.1029/2005WR004387

Barnett, T. P., Adam, J. C., \& Lettenmaier, D. P. (2005). Potential impacts of a warming climate on water availability in snow-dominated regions. Nature, 438(7066), 303-309. https://doi.org/10.1038/nature04141

Belart, J. M. C., Berthier, E., Magnússon, E., Anderson, L. S., Pálsson, F., Thorsteinsson, T., et al. (2017). Winter mass balance of Drangajökull ice cap (NW Iceland) derived from satellite sub-meter stereo images. The Cryosphere, 11(3), 1501-1517. https://doi.org/ 10.5194/tc-11-1501-2017

Berthier, E., Arnaud, Y., Kumar, R., Ahmad, S., Wagnon, P., \& Chevallier, P. (2007). Remote sensing estimates of glacier mass balances in the Himachal Pradesh (Western Himalaya, India). Remote Sensing of Environment, 108(3), 327-338. https://doi.org/10.1016/j.rse.2006.11.017

Boisier, J. P., Rondanelli, R., Garreaud, R. D., \& Muñoz, F. (2016). Anthropogenic and natural contributions to the Southeast Pacific precipitation decline and recent megadrought in Central Chile. Geophysica, 43, 413-421. https://doi.org/10.1002/2015GL067265

Brock, B. W., Willis, I. C., \& Sharp, M. J. (2000). Measurement and parameterization of albedo variations at Haut Glacier d' Arolla, Switzerland. Journal of Glaciology, 46(155), 675-688. https://doi.org/10.3189/172756500781832675

Brown, M. E., Racoviteanu, A. E., Tarboton, D. G., Gupta, A. S., Nigro, J., Policelli, F., et al. (2014). An integrated modeling system for estimating glacier and snow melt driven streamflow from remote sensing and earth system data products in the Himalayas. Journal of Hydrology, 519, 1859-1869. https://doi.org/10.1016/j.jhydrol.2014.09.050

Bühler, Y., Adams, M. S., Bösch, R., \& Stoffel, A. (2016). Mapping snow depth in alpine terrain with unmanned aerial systems (UASs): Potential and limitations. The Cryosphere, 10(3), 1075-1088. https://doi.org/10.5194/tc-10-1075-2016

Burger, F., Ayala, A., Farias, D., Shaw, T. E., Macdonell, S., Brock, B., et al. (2018). Interannual variability in glacier contribution to runoff from a high - elevation Andean Catchment: Understanding the role of debris cover in glacier hydrology. Hydrological Processes, SI-Latin (January), 33(2), 214-229. https://doi.org/10.1002/hyp.13354

Burger, F., Brock, B., \& Montecinos, A. (2018). Seasonal and elevational contrasts in temperature trends in Central Chile between 1979 and 2015. Global and Planetary Change, 162, 136-147. https://doi.org/10.1016/j.gloplacha.2018.01.005

Cornwell, E., Molotch, N. P., \& Mcphee, J. (2016). Spatio-temporal variability of snow water equivalent in the extra-tropical Andes cordillera from distributed energy balance modeling and remotely sensed snow cover. Hydrology and Earth System Sciences, 20(1), 411-430. https://doi.org/10.5194/hess-20-411-2016

Cortés, G., Girotto, M., \& Margulis, S. (2016). Snow process estimation over the extratropical Andes using a data assimilation framework integrating MERRA data and Landsat imagery. Water Resources Research, 52, 2582-2600. https://doi.org/10.1002/2015WR018376

Essery, R., Li, L., \& Pomeroy J. (1999). A distributed model of blowing snow over complex terrain. Hydrological Processes, 13(14-15), 2423-2438. https://doi.org/10.1002/(sici)1099-1085(199910)13:14/15<2423::aid-hyp853>3.0.co;2-u

Favier, V., Falvey, M., Rabatel, A., Praderio, E., \& Lo, D. (2009). Interpreting discrepancies between discharge and precipitation in high-altitude area of Chile' s Norte Chico region (26-32 ${ }^{\circ}$ S). Water Resources Research, 45, W02424. https://doi.org/10.1029/2008WR006802

Finger, D., Pellicciotti, F., Konz, M., Rimkus, S., \& Burlando, P. (2011). The value of glacier mass balance, satellite snow cover images, and hourly discharge for improving the performance of a physically based distributed hydrological model. Water Resources Research, 47, W07519. https://doi.org/10.1029/2010WR009824

Fischer, M., Huss, M., Kummert, M., \& Hoelzle, M. (2016). Application and validation of long-range terrestrial laser scanning to monitor the mass balance of very small glaciers in the Swiss Alps. The Cryosphere, 10(3), 1279-1295. https://doi.org/10.5194/tc-10-1279-2016

Flerchinger, G. N., \& Saxton, K. E. (1989). Simultaneous heat and water model of a freezing snow-residue-soil system I. theory and development. American Society of Agricultural and Biological Engineers, 32(2), 565-571. https://doi.org/10.13031/2013.31040

Freudiger, D., Kohn, I., Seibert, J., Stahl, K., \& Weiler, M. (2017). Snow redistribution for the hydrological modeling of alpine catchments. Wiley Interdisciplinary Reviews: Water, 4(5), e1232. https://doi.org/10.1002/wat2.1232 
Garreaud, R. D., Alvarez-Garreton, C., Barichivich, J., Boisier, J. P., Christie, D., Galleguillos, M., et al. (2017). The 2010-2015 megadrought in Central Chile: Impacts on regional hydroclimate and vegetation. Hydrology and Earth System Sciences, 21(12), 6307-6327. https://doi. org/10.5194/hess-21-6307-2017

Garreaud, R. D., Boisier, J. P., Rondanelli, R., Montecinos, A., \& Veloso-aguila, H. H. S. D. (2019). The Central Chile mega drought (20102018): A climate dynamics perspective. International Journal of Climatology, 40(1), 421-439. https://doi.org/10.1002/joc.6219

Gascoin, S., Lhermitte, S., Kinnard, C., Bortels, K., \& Liston, G. E. (2013). Wind effects on snow cover in Pascua-Lama, Dry Andes of Chile. Advances in Water Resources, 55, 25-39. https://doi.org/10.1016/j.advwatres.2012.11.013

Goetz, J., \& Brenning, A. (2019). Quantifying uncertainties in snow depth mapping from structure from motion photogrammetry in an alpine area. Water Resources Research, 55, 7772-7783. https://doi.org/10.1029/2019WR025251, 9

Grünewald, T., Stötter, J., Pomeroy, J. W., Dadic, R., Moreno Baños, I., Marturià, J., et al. (2013). Statistical modelling of the snow depth distribution in open alpine terrain. Hydrology and Earth System Sciences, 17(8), 3005-3021. https://doi.org/10.5194/hess-17-3005-2013

Gupta, H. V., Kling, H., Yilmaz, K. K., \& Martinez, G. F. (2009). Decomposition of the mean squared error and NSE performance criteria: Implications for improving hydrological modelling. Journal of Hydrology, 377(1-2), 80-91. https://doi.org/10.1016/j.jhydrol.2009.08.003

Gutmann, E., Barstad, I., Clark, M., Arnold, J., \& Rasmussen, R. (2016). The intermediate Complexity Atmospheric Research model (ICAR). Journal of Hydrometeorology, 17(3), 957-973. https://doi.org/10.1175/JHM-D-15-0155.1

Hall, D. K., Riggs, G. A., Foster, J. L., \& Kumar, S. V. (2010). Remote sensing of environment development and evaluation of a cloud-gapfilled MODIS daily snow-cover product. Remote Sensing of Environment, 114(3), 496-503. https://doi.org/10.1016/j.rse.2009.10.007

Hedrick, A., States, U., Marks, D. G., Marshall, H., \& Bormann, K. J. (2018). Direct insertion of NASA airborne snow observatory-derived snow depth time series into the iSnobal energy balance snow model direct insertion of NASA airborne snow observatory-derived snow depth time series into the iSnobal energy balance snow model. Water Resources Research, 54, 8045-8063. https://doi.org/10.1029/2018WR023190

Houze, R. A. Jr. (2012). Orographic effects on precipitating clouds. Reviews of Geophysics, 50, RG1001. https://doi.org/10.1029/2011RG000365

Jarosch, A. H., Anslow, F. S., \& Clarke, G. K. C. (2012). High-resolution precipitation and temperature downscaling for glacier models. Climate Dynamics, 38(1-2), 391-409. https://doi.org/10.1007/s00382-010-0949-1

Jonas, T., Marty, C., \& Magnusson, J. (2009). Estimating the snow water equivalent from snow depth measurements in the Swiss Alps. Journal of Hydrology, 378(1-2), 161-167. https://doi.org/10.1016/j.jhydrol.2009.09.021

Kormos, P., Luce, C. H., Wenger, S. J., \& Berghuijs, W. R. (2016). Trends and sensitivities of low streamflow extremes to discharge timing and magnitude in Pacific Northwest mountain streams. Water Resources Research, 52, 4990-5007. https://doi.org/10.1002/2015WR018125

Lane, S. N., \& Nienow, P. W. (2019). Decadal-scale climate forcing of alpine glacial hydrological systems. Water Resources Research, 55(3), 2478-2492. https://doi.org/10.1029/2018wr024206

Li, D., Lettenmaier, D. P., Margulis, S. A., \& Andreadis, K. (2019). The value of accurate high-resolution and spatially continuous snow information to streamflow forecasts. Journal of Hydrometeorology, 20(4), 731-749. https://doi.org/10.1175/JHM-D-18-0210.1

Li, H., Luo, L., Wood, E. F., \& Schaake, J. (2009). The role of initial conditions and forcing uncertainties in seasonal hydrologic forecasting. Journal of Geophysical Research, 114, D04114. https://doi.org/10.1029/2008JD010969

López-Moreno, J. I., Fassnacht, S. R., Heath, J. T., Musselman, K. N., Revuelto, J., Latron, J., et al. (2013). Small scale spatial variability of snow density and depth over complex alpine terrain: Implications for estimating snow water equivalent. Advances in Water Resources, 55, 40-52. https://doi.org/10.1016/j.advwatres.2012.08.010

López-Moreno, J. I., \& Nogués-Bravo, D. (2006). Interpolating local snow depth data: An evaluation of methods. Hydrological Processes, 20(10), 2217-2232. https://doi.org/10.1002/hyp.6199

Mankin, J. S., Viviroli, D., Singh, D., Hoekstra, A. Y., \& Diffenbaugh, N. S. (2015). The potential for snow to supply human water demand in the present and future. Environmental Research Letters, 10(11), 114016. https://doi.org/10.1088/1748-9326/10/11/114016

Margulis, S. A., \& Fang, Y. (2019). The utility of infrequent snow depth images for deriving continuous space-time estimates of seasonal snow water equivalent. Geophysical Research Letters, 46, 5331-5340. https://doi.org/10.1029/2019GL082507

Marks, D., \& Dozier, J. (1992). Climate and energy exchange at the snow surface in the Alpine region of the Sierra Nevada. 2. Snow cover energy balance. Water Resources Research, 28(11), 3043-3054. https://doi.org/10.1029/92WR01483

Marti, R., Gascoin, S., Berthier, E., De Pinel, M., Houet, T., \& Laffly, D. (2016). Mapping snow depth in open alpine terrain from stereo satellite imagery. The Cryosphere, 10(4), 1361-1380. https://doi.org/10.5194/tc-10-1361-2016

McGrath, D., Webb, R., Shean, D., Bonnell, R., \& Marshall, H. P. (2019). Spatially extensive ground-penetrating radar snow depth observations during NASA's 2017 SnowEx campaign: Comparison with in situ, airborne, and satellite observations. Water Resources Research, 55, 10,026-10,036. https://doi.org/10.1029/2019WR024907

Mendoza, P. A., Rajagopalan, B., Clark, M. P., Cortes, G., \& McPhee, J. (2014). A robust multi-model framework for ensemble seasonal hydroclimatic forecasts. Water Resources Research, 50, 6030-6052. https://doi.org/10.1002/2014WR015426

Mernild, S. H., Liston, G. E., Hiemstra, C. A., Malmros, J. K., Yde, J. C., \& Mcphee, J. (2016). The Andes Cordillera. Part I: Snow distribution, properties, and trends (1979-2014). International Journal of Climatology, 37(4), 1680-1698. https://doi.org/10.1002/joc.4804

Meza, F. J., Vicuna, S., Gironás, J., Poblete, D., Suárez, F., \& Oertel, M. (2015). Water-food-energy nexus in Chile: The challenges due to global change in different regional contexts. Water International, 40(5-6), 839-855. https://doi.org/10.1080/02508060.2015.1087797

Meza, F. J., Wilks, D. S., Gurovich, L., \& Bambach, N. (2012). Impacts of climate change on irrigated agriculture in the Maipo Basin, Chile: Reliability of water rights and changes in the demand for irrigation. Journal of Water Resources Planning and Management, 138(5), 491-501. https://doi.org/10.1061/(ASCE)WR.1943-5452

Moore, R. D. D. (2004). Introduction to salt dilution gauging for streamflow measurement: Part I. Streamline Watershed Management Bulletin, 7(4), 20-23.

Musselman, K. N., Pomeroy, J. W., Essery, R. L. H., \& Leroux, N. (2015). Impact of windflow calculations on simulations of alpine snow accumulation, redistribution and ablation. Hydrological Processes, 29(18), 3983-3999. https://doi.org/10.1002/hyp.10595

Nolin, A. W., Phillippe, J., Jefferson, A., \& Lewis, S. L. (2010). Present-day and future contributions of glacier runoff to summertime flows in a Pacific Northwest watershed: Implications for water resources. Water Resources Research, 46, W12509. https://doi.org/10.1029/ 2009WR008968

Ohlanders, N., \& Mcphee, J. (2013). Stable water isotope variation in a central Andean watershed dominated by glacier and snowmelt dominated by glacier and snowmelt. Hydrology and Earth System Sciences, 17(3), 1035-1050. https://doi.org/10.5194/hess-17-1035-2013

Painter, T. H., Berisford, D. F., Boardman, J. W., Bormann, K. J., \& Deems, J. S. (2016). The airborne snow observatory: Fusion of scanning lidar, imaging spectrometer, and physically-based modeling for mapping snow water equivalent and snow albedo. Remote Sensing of Environment, 184(July), 139-152. https://doi.org/10.1016/j.rse.2016.06.018

Ragettli, S., Cortés, G., Mcphee, J., \& Pellicciotti, F. (2014). An evaluation of approaches for modelling hydrological processes in highelevation, glacierized Andean watersheds. Hydrological Processes, 28(23), 5674-5695. https://doi.org/10.1002/hyp.10055 
Ragettli, S., Immerzeel, W. W., \& Pellicciotti, F. (2016). Contrasting climate change impact on river flows from high-altitude catchments in the Himalayan and Andes Mountains. Proceedings of the National Academy of Sciences, 113(33), 9222-9227. https://doi.org/10.1073/ pnas. 1606526113

Ragettli, S., \& Pellicciotti, F. (2012). Calibration of a physically based, spatially distributed hydrological model in a glacierized basin: On the use of knowledge from glaciometeorological processes to constrain model parameters. Water Resources Research, 48 , W03509. https://doi.org/10.1029/2011WR010559

Ragettli, S., Pellicciotti, F., Immerzeel, W. W., Miles, E. S., Petersen, L., Heynen, M., et al. (2015). Unraveling the hydrology of a Himalayan catchment through integration of high resolution in situ data and remote sensing with an advanced simulation model. Advances in Water Resources, 78, 94-111. https://doi.org/10.1016/j.advwatres.2015.01.013

Raleigh, M. S., \& Small, E. E. (2017). Snowpack density modeling is the primary source of uncertainty when mapping basin-wide SWE with lidar. Geophysical Research Letters, 44, 3700-3709. https://doi.org/10.1002/2016GL071999

Redpath, T. A. N., Sirguey, P., \& Cullen, N. J. (2018). Repeat mapping of snow depth across an alpine catchment with RPAS photogrammetry. The Cryosphere, 12(11), 3477-3497. https://doi.org/10.5194/tc-12-3477-2018

Réveillet, M., McDonnell, S., Gascoin, S., Kinnard, C., Lhermitte, S., \& Schaffer, N. (2020). Impact of forcing on sublimation simulations for a high mountain catchment in the semiarid Andes. The Cryosphere, 14(1), 147-163. https://doi.org/10.5194/tc-14-147-2020

Revuelto, J., López-Moreno, J. I., Azorin-Molina, C., \& Vicente-Serrano, S. M. (2014). Topographic control of snowpack distribution in a small catchment in the central Spanish Pyrenees: Intra- and inter-annual persistence. The Cryosphere, 8(5), 1989-2006. https://doi.org/ $10.5194 /$ tc-8-1989-2014

Riedel, J. L., Wilson, S., Baccus, W., \& Larrabee, M. (2015). Glacier status and contribution to Streamflow in the Olympic Mountains, USA Journal of Glaciology, 61(225), 8-16. https://doi.org/10.3189/2015JoG14J138

Roth, A., Hock, R., Schuler, T. V., Bieniek, P. A., Pelto, M., \& Aschwanden, A. (2018). Modeling winter precipitation over the Juneau Icefield, Alaska, using a linear model of orographic precipitation. Frontiers in Earth Science, 6(March), 1-19. https://doi.org/10.3389/feart.2018.00020

Scaff, L., Rutllant, J., Rahn, D., Gascoin, S., \& Rondanelli, R. (2017). Meteorological interpretation of orographic precipitation gradients along an Andes west Slope Basin at 30 S (Elqui Valley, Chile). Journal of Hydrometeorology, 18(3), 713-727. https://doi.org/10.1175/ JHM-D-16-0073.1

Sevruk, B., Ondrás, M., \& Chvíla, B. (2009). The WMO precipitation measurement intercomparisons. Atmospheric Research, 92(3), 376-380. https://doi.org/10.1016/j.atmosres.2009.01.016

Shaw, T. E., Caro, A., Mendoza, P., Ayala, Á., Pellicciotti, F., Gascoin, S., \& McPhee, J. (2020). Winter snow depths for initializing a glacio-hydrological model in high mountain Chile. Zenodo Data Repository. https://doi.org/10.5281/zenodo.3613951. Available at: https://zenodo.org/record/3613951\#.XiYSKkaJKUk

Shaw, T. E., Gascoin, S., Mendoza, P. A., Pellicciotti, F., \& McPhee, J. (2020). Snow depth patterns in a High Mountain Andean catchment from satellite optical tri-stereoscopic remote sensing. Water Resources Research, 56, e2019WR024880. https://doi.org/10.1029/ 2019WR024880

Shean, D. E., Alexandrov, O., Moratto, Z. M., Smith, B. E., Joughin, I. R., Porter, C., \& Morin, P. (2016). An automated, open-source pipeline for mass production of digital elevation models (DEMs) from very-high-resolution commercial stereo satellite imagery. ISPRS Journal of Photogrammetry and Remote Sensing, 116, 101-117. https://doi.org/10.1016/j.isprsjprs.2016.03.012

Shrestha, M., Koike, T., Hirabayashi, Y., Xue, Y., Wang, L., Rasul, G., \& Ahmad, B. (2015). Integrated simulation of snow and glacier melt in water and energy balance-based, distributed hydrological modeling framework at Hunza River basin of Pakistan Karakoram region Maheswor. Journal of Geophysical Research: Atmospheres, 120, 4889-4919. https://doi.org/10.1002/2014JD022666

Stehr, A., \& Aguayo, M. (2017). Snow cover dynamics in Andean watersheds of Chile (32.0-39.5S) during the years 2000-2016. Hydrology and Earth System Sciences, 21, 5111-5126, 10. https://doi.org/10.5194/hess-21-5111-2017

Stigter, E. E., Wanders, N., Saloranta, T. M., Shea, J. M., \& Bierkens, M. F. P. (2017). Assimilation of snow cover and snow depth into a snow model to estimate snow water equivalent and snowmelt runoff in a Himalayan catchment. The Cryosphere, 11(4), 1647-1664. https://doi. org/10.5194/tc-11-1647-2017

Sturm, M., Taras, B., Liston, G. E., Derksen, C., Jonas, T., \& Lea, J. (2010). Estimating snow water equivalent using snow depth data and climate classes. Journal of Hydrometeorology, 11(6), 1380-1394. https://doi.org/10.1175/2010JHM1202.1

Trujillo, E., Ramírez, J. A., \& Elder, K. J. (2007). Topographic, meteorologic, and canopy controls on the scaling characteristics of the spatial distribution of snow depth fields. Water Resources Research, 43, W07409. https://doi.org/10.1029/2006WR005317

Vionnet, V., Martin, E., Masson, V., Lac, C., Naaim Bouvet, F., \& Guyomarc'h, G. (2017). High-resolution large eddy simulation of snow accumulation in Alpine terrain. Journal of Geophysical Research: Atmospheres, 122, 11,005-11,021. https://doi.org/10.1002/ 2017JD026947

Viviroli, D., Dürr, H. H., Messerli, B., Meybeck, M., \& Weingartner, R. (2007). Mountains of the world, water towers for humanity: Typology, mapping, and global significance. Water Resources Research, 43, W07447. https://doi.org/10.1029/2006wr005653

Xu, C., Li, Z., Li, H., Wang, F., \& Zhou, P. (2019). Long-range terrestrial laser scanning measurements of annual and intra-annual mass balances for Urumqi Glacier No. 1, eastern Tien Shan, China. The Cryosphere, 13(9), 2361-2383. https://doi.org/10.5194/tc-13-2361-2019

\section{References From the Supporting Information}

Brock, B. W., Mihalcea, C., Kirkbride, M. P., Diolaiuti, G., Cutler, M. E. J., \& Smiraglia, C. (2010). Meteorology and surface energy fluxes in the 2005-2007 ablation seasons at the Miage debris-covered glacier, Mont Blanc Massif, Italian Alps. Journal of Geophysical Research, 115, D09106. https://doi.org/10.1029/2009JD013224

Carenzo, M., Pellicciotti, F., Mabillard, J., Reid, T., \& Brock, B. W. (2016). An enhanced temperature index model for debris-covered glaciers accounting for thickness effect. Advances in Water Resources, 94, 457-469. https://doi.org/10.1016/j.advwatres.2016.05.001

Krajci, P., Holko, L., Perdigao, R. A. P., \& Parajka, J. (2014). Estimation of regional snowline elevation (RSLE) from MODIS images for seasonally snow covered mountain basins. Journal of Hydrology, 519(PB), 1769-1778. https://doi.org/10.1016/j.jhydrol.2014.08.064

Reid, T. D., \& Brock, B. W. (2010). An energy-balance model for debris-covered glaciers including heat conduction through the debris layer. Journal of Glaciology, 56(199), 903-916. https://doi.org/10.3189/002214310794457218

Shaw, T. E., Brock, B., Fyffe, C., Pellicciotti, F., Rutter, N., \& Diotri, F. (2016). Air temperature distribution and energy balance modelling of a debris-covered glacier. Journal of Glaciology, 62(231), 1-14. https://doi.org/10.1017//jog.2016.31

Shea, J. M., \& Moore, R. D. (2010). Prediction of spatially distributed regional-scale fields of air temperature and vapor pressure over mountain glaciers. Journal of Geophysical Research, 115, D23107. https://doi.org/10.1029/2010JD014351 